\title{
7) 麻骖に関する基礎的研究
}

\author{
代表者 䤰 洞 醇 太郎 (大阪大学教授, 微生物病研究所)
}

\section{班員および分担研究課題}

1 麻疹の腎染病理阪大微研教授 釜洞醇太郎

2 麻疹ウィルスの変異 阪大微研教授 奥野 良臣

3 ウイルズによるシンシテウム形成の機構

東北头，医，教授 石田名香雄

4 麻疹ウイルスの基礎的研究

5 麻疹以関臭る基礎的研究

大阪府公衆衛生研 国田 信治

6 麻疹江関する基礎的研究

東大伝研教授 松本 稔

岡山大，医，助教授 俵 寿太郎

7 麻疹红関する基礎的研究

国立予研公辰 宾戸 亮

8 マウス脳親和性はしかウィルスによるマウス及び八 ムスタ一脳炎の形態学的研究

東大伝研教授 草野 信男

総合班編成第二年目の成績は，順調である。驻しかウ イルスが, 純学問的に研究される段階になった。最も進 んだのは，はしか感染の Pathogenese の研究である。 古らゆるウイルス病の感染病理のうち, 最も克明化画き 出されつつあるものと考光る。ウイルスの変異の問題は ワクチン改良の必要性から重要であるが未だ， marker の確立党見ない。多くの班員が競って plaque 法の研究 に邁進しはじめたのは当然である。又 Interferon の存 在も，肯定されるととろであり，将来期待されるとてろ 大である。抗元性の問題は仲々複雑であるが, 凝集素に 関しては，深くつってんだ研究がなされ，スェーデンの Norby 等としのぎをけずっている。電子顕微鏡的研究 も急速の充実を見せ国際的水準㑢しつつあるの佯喜ば しい。更に来年は，一段の飛躍が期待される。

八ムスターに脳炎を起さしめる研究もニニークなもの であり，一方，巨細胞形成のメカニズム点 RS ウイルス についてであるが，閺明しつつあるの性大きな希望芭持 たしめるもので㐫る。

来年度は，いよい上，日本麻疹学の優秀性觉発揮する てとを確信するものである。

\section{1. 麻疹の感染病理}

実験方法：サル感染実験

結果：サル纯 non-immune のもの光らふてとが 出来たので, 病変は顕著であった。血中抗体 $(\mathrm{CF}$ ，中 和）の測定㹥注射前と, 二週間後屠殺時との二回行っ た。得られた処見壱列記すると

1.リンパ系汇出現する巨細胞汕二種類である。即ち Warthin·Finkeldy 型と細綢細胞系で䆚る。前者は vi rologically passive giant-cell, 後者,. virologically active giant-cell と胃做され, 後者㲹は, 核内, 細胞 質内封入体が存在する。

2. 抗体上某を見ないサルの病変は揃って影著である。 特に，抗体上其零のもの亿扔いては，Giant cell pneumonia (Hecht's disease) の発生觉見た。逆に Hecht's disease の etiology の確立に資するとてろ大であると 思う。

3. 患者材料の Koplik 発生後 rash のない時期にと られたものは, 強力な感染性があるが, rash 出現後, 1,2.3 日と経過する亿つ机て，その力は㧍と万光，3日 では殆んど毒力住零である。

4. 二種類の封入体の消長には差異が甶る。WarthinFinkeldy 住一週間以後消失するに反し, reticulum cell giant cell の方蛙半月老経過しても残存する。前者仙抗 体の元いきようを受け，後者は受けない样に招もわれる

5. 感染はりンパ系にはじまり, spread し第二次的に 固有の粘膜に及ぶようである。その場所は, 呼吸器, 消 化器; 泌尿器系汇及ぶ。

以上の研究は 1964 年パリで開か礼た Seminar on measles and rubella の原上で発表した。

発表 :

Archiv für Virusforschung. 印刷中

2. 麻掺ウイルスの変異

奥野良臣

研究目標：現在麻疹ウイルスの弱毒株が得られてい 
て，麻将のワクチンに応用されている。しかし代表的な 数種の株你自然強瑇株に比しサルや人に於ける反応性に 相異は認められるが，生ワクチンとしては不充分な弱毒 である。そてで更に弱毒株を得るために先ず弱毒過程在 知るための一次的な手段てして従来の增殖用細胞とは別 の細胞で增殖させるか異った条件で増殖させて生じたウ イルスの性状を検べるととした。

研究方法：麻疹的イルスは豊島株発育鷂卵羊膜腔継代 のもの者用い，継代方法として次の 5 つの方法を選ん t。

1. 従来の通り発育鶏卵羊膜継代の長期通過

2. 同継代の低温 $\left(32^{\circ} \mathrm{C}\right)$ 通過

3. 漿层膜及び羊膜腔交互継代法

4. 嶈尿膜継代

5. 漿尿膜低温培養

以上の方法に上るウイルス゚增殖程度と反応性を検べ る。

研究経過：発育鵎卵羊膜腔継代では 20～約 100 世代の 間では継代数の如何にかかわらず，ウィルスの增殖程度 と弱毒性に変化は認められなかった。漿尿腔と羊膜腔の 交互継代は長期に亘って継代可能である。また漿尿舫だ けでも麻疹ウイルス约継代可能であるが，FL 細胞们刘 する細胞病原性注 6 世代以降見られなくなる。しかしそ れ以後の世代に於てもウイルスが増殖しているととは他 のウイルスとの干涉現象を目標として証明できだ。

$32^{\circ} \mathrm{C}$ の低温培養法では, 羊膜腔継代では $35^{\circ} \mathrm{C} の$ 場合 とウイルスの增殖に差起見ない。極端の例として $28^{\circ} \mathrm{C}$ でも鷄胚の発育㹥綛められないにも不拘ウイルスはかな りよく增殖走示した。

以上のいずれの場合に增殖したウイルスる人に対する 反応性は原株と著差認訲るととはできなかった。

考察：継代方法の相違によって弱毒変異株を得るてと 住困難で岗ると考光られるので，プラーキングによる分

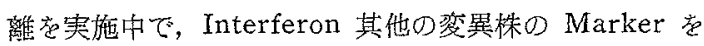
得る実験噼考慮している。

発表:

Archiv für Virusforschung. 印刷中

3. ウイルスに上るシンシチウム形成の機構 石田名香雄

（拹力者：日沼頼夫，茂田士郎）

研究成果：シンシチウムをつくるウィルスには RNA ウイルスとしてハシカ，パラインフルエンザ及び RS が あり，DNA ウイルスとしてへルペス，ポックスなどが
ある。前者の RNA ウイルス群伎血清学的に全く異るウ イルスであるが，その粒子構造も生物学的性状もよく類 似している。我々はての RNA ウイルス群のうちから RS ウイルスを材料として，とのウィルスのシンシチウ ム形成機構を追跡した。実験に用いだィルスは Long 株, 細胞仙 HEp-2で, 培養液估 Eagle's MEM, $33^{\circ} \mathrm{C}$ で静置培養芭行った。

$\mathrm{MOI}=1 / 200$ でウイルス感染をすすめた場合に，10時 間前後で新しい感染性ウイルスの立上りを示し，以後 30 時間まで対数的に增加する。ての間ウイルス抗原合成細 胞を篮光抗体法で追跡してゆくと，10時間でずでにウイ ルス抗原合成細胞が元光はじめ，その数は增加してゅく が 16 時間頃よりウイルス抗原保有の細胞融合（小さい シンシチウム形成）が出現しはじめ，以後その数とシン シチウムの大きさが增加するが，てのシンシチウム形成 の発端である細胞融合は，感染細胞と非感染細胞間でお こるととがわかった。ヌウイルス吸着後，抗ウイルス血 清を含む培養液中で感染を進めてもシンシテウム形成は 扣とるととが認められた。

以上の実験事実汃ら本ウィルスと細胞との interactionは次のようにまとめるととが出来る。

(1) ウイルス感染細胞のウィルス合成が進行するとそ の細胞表面は修飾されるためと非感染細胞との接触部位 で雨者細胞表面の細胞膜は開裂して互の細胞質の交流が おこり，それは 2 ケ以上の核をもつ感染細胞となる。乙 の反応の連続がシンシテウムの発庋である。

(2) 細胞融合は抗ウイルス血清で阻碍され始点から゙み て, 融合飞必要な細胞表面の修飾はウイルス抗原と直接 関係のない因子を考えてよい。

(3) シンシチウムの発屡はウイルス合成の進行を阻碍 してない点加らて，細胞融合による細胞質の交流々い う物理的変化はウイルス合成にあずかる細胞搆造を損稘 するというととはない。

(4) てのウイルスの細胞集団に於ける忶播仙 cell to cell infection の漛式が主であり，細胞外化放出された 粒子加らの吸着, 侵入のステップ范とる様式はむしろ従 であろうと考元られる。

4. 麻翏ウイルスの基礎的研究, 麻疹ウイルス の抗原性に関する研究

国由信治

（拹力者：豊島久真男，北脇達雄，大津啓二）

研究目的：麻疹ウイルスについては感染性以外に，補 体結合, 赤血球凝集, 溶血, 巨細胞形成等の性質が知ら 
れているが，てれ等抗原相互の関連と, 夫夫々の持つ意義 に関して研究し，今後の麻疹及び麻疹ウイルスに関する 研究の基礎資料堂ととのえたい。

\section{本年度の成果 :}

1. ウイルス継代緇胞株の種類による麻疹赤血球凝集素 の性質の相違について

前年度研究中に, $\mathrm{KB}$ 細胞継代株と, $\mathrm{FL}$ 細胞継代株 間に,エーテル-Tween 80 処理について 明らかな性質 の差がみとめられた。その差が抗原の各プールのばらつ きでないととを確かめるため, 本年は, 約 $500 \mathrm{ml}$ の抗 原プールを FL 継代抁原として 15 プール， KB 継代と して19プールとり，エーテルーTween 80 処理を試みた。

$\mathrm{FL}$ 継代については，1/15 が2 倍の赤血球凝集価上年 をみ，3/15が 1/2 程度の低下を示した。測定法の誤差 を考え机ば，乙礼は本処理によって，赤血球凝集価は変 らなかったと結論していいと考えられる。KB 縊代のも のは 19/19 が上果し，平均 4 倍の上昇がみられる。この 性質については宿主存変えて，1代継代しても変化はみ られない。現在その差の原因，抽とりうる時期等につい て検討を加えている。

2. 各種抗原性の関連について

前年迄の研究に引続いて, 巨細胞形成能, 溶血能老加 え検討した。各種ウイルスプールについての検討結果， 巨細胞形成能と，溶血能住可成平行するが，これらと， 赤血球凝集能とは一定の関連性のないととが判っだ。更 に蓔糖濃度勾配遠心法により分析すると, 赤如球凝集素 は未精製材料では多数のピークを形成し，溶血能はその 2. 3 のピークに一致してあらわれて来るように考えられ る。しかし溶血能は現在の所主として感染俩の存在する 最も重い分劃に主として存在し，巨細胞形成能は後者に しか証明されない。乙れが抗原濃度の差か，もうと質的 な相違汃について, 現在検討を進めつつある。

\section{発表 :}

昨年度迄のものについての発表

Purification and Some Antigenic Properties of Measles Virus Hemagglutinin. Biken J. 6, 253 270 (1964).

本年度のものは未発表

\section{5. 麻㾸に関する基礎的研究。}

松本稔

（協力者：小田昌彦，有田峯生） ハシカウイルスの増殖に打よぼす. Actinomycin D の 影響
ハシカウイルス杉山株をヒト羊膜 $\mathrm{FL}$ 細胞などの培善 細胞に感染させ，その増殖態度をしらべると，他のウイ ルスに比し，增殖が扣そく，えられるウイふス量も比較 的少ないととは，てれまでしばしば経験したととろであ る。とれは，八シカウィルスを定量的研究しようとす るとき，第一にぶつかる難点であろう。そてで，私ども はまず高濃度のウイルスをうる条件をしらべ，その上で ハシカウイルスの増殖を追跡しようとして㬰験をはじめ た。

実験に先だち，ウィルズ定量の精度をあげるだめて れまでの試験管法による定量からプラック法にきりかえ た。杉山株のFL 細胞上のプラックは，その大きさがか なりまちまちであったので, 比較的大きなプラックから クローンをくりかえしとり，かなり均一な大きなプラッ クを作るウイルスをえたしとは前年の研究報告でのべた が，今年の研究はこのウイルスについて行われた。前年 の研究から，プラック法の条件は，FL 細胞 1 日培養に. ウィルス液 (YLE 液で稀橎) を $0.2 \mathrm{ml}$ 接種し, $37^{\circ} \mathrm{C}$ で 90 分吸着を打てない，ついで $0.6 \%$ 亿寒天をふくむ $4 \%$ ウシ血清加 YLE 液を重層し $\mathrm{CO}_{2}$ ふらん器で 5 日 間培養するという方法である。5 日後に中性紅液で染色 してプラック数芷えた。

まず，FL 細胞にウイルスをウイルス細胞比 0.001 で 感染させ，日を扣ってウイルスの増殖をしらべた。ての 場合増殖は非常に打そく，4 日後に細胞内ウイルス量は 最高值にたっした。をこで，最高值を示したウィルス材 料を次の接種に用い, 第2 回の実験を行った。このとき のウイルス細胞比は 0.01 であった。すると, 第 1 回の 実験より增殖は速く，2 日で最高值をしめし，その值む 高かった。てれをまた次の接種ウイルスに用いるという ように, 次々と接種ウィルス量を高くして, ウイルス緅 胞比起 1.0 にとると，潜伏期はさらに短く，18時間にな り，36時間で 細胞内ウイルスは最高となったが，その 值は前回の実験值とそれほど変らなかった。

そこでての条件で大量のウィルスを作り遠心濃縮して 20 というウイルス細胞比で増殖実験を行っだ。との場 合には，潜伏期は 10 時間に短縮しだ。㕲そらくしれが 一段増殖に扣ける潜伏期と思われる。しかしこの場合に も, 細胞内ウイルスの最高值ば前回の実験と差がなかっ t:。

とのような；えられるウイルス量が低いというととの 原因に，何か別の因子を考えなくてはいけない。その一 つは阻止因子で，まずインターフェロンが考学られよ う。Arbovirus の実験によると，Actinomycin Dはウ 
イルス增殖を㧊さえず，しかもインターフェロンの産生 を阻止するといわれている。るし本系化てのような阻止 因子於介入しているとすれば, Actinomycin D で八シ カウイルスの增殖を促進できる可能性がある。

そてで，FL 細胞们ィルス汒感染させ，維持液に Actinomycin D $(0.1 \mu \mathrm{g} / \mathrm{ml})$ を加えてウイルス增殖を しらべた。接種のウイルス細胞比を１としたとき，薬剤 を加えることにより，ハシカウイル之の細胞内增殖速度 をはやめ，乙か毛対照より高いウイルス量克うるととが できた。しかし，ウイルス細胞比を20にすると，増殖 速度は大きくなが，えられるウイルスの最高值虫対照 とほとんど変らな加った。要するに，Actinomycin D は八シカウイルスの細胞内增殖を阻害しないばかりでな くかえってその増殖速度走促進するてとは，たしかであ り，とれは薬剤が細胞のウイルス增殖にたいする抑制機 構を何らかの形で抑えるためと考元られる。てれにイン ターフェロンが㗢いている可能性があり，目下その存在 をたしかめる実験を行なっている。さらに, Actinomycin Dがどのようにして增殖速度を促進するのか，また ウイルス感染細胞に扢てる他の変化にどのような影響を 与えるのか下検討中である。さらに最初計画した，高 濃度のウイルス材料をえる方法の検討は一段增殖を扣と ない，遠心濃縮を併用するととで一応目的は，はたした が，他のより簡便な方法があるか，西るとすればどのよ うな条件（機構もふくめて）で作りうるかについてもあ わせて実験してゆきたいと考えている。

\section{6. 麻嗞に関する基礎的研究}

\section{俵 着太郎}

(1) 麻沴ウイルスによる細胞変性効果の出現（医学々 生物学 68 巻 192 195, 1964)

麻疹ウイルスの感染標識とされている細胞変性効果 (CPE) 沙，一般的には，線維芽㥞細胞变性，多核巨大 細胞形成及び封入体形成（細胞質内及び核内）等であ る。これら CPE 出現の時間的関係と形態的変化の過程 と芦，数種類の細胞につにて観察した。

英験材料及び方法：使用した細胞社 FL 細胞, HeLa 細胞, JTC-3 細胞, 犬緊細胞及び八ムスタ一腎縉胞で ある。てれらの細胞数方各試験管に 20 万一 30 万 $/ \mathrm{ml} に$ なった時にウイルスを接種し，毎日各細胞について 3 本 の試跧管からカバースリップを取出しへマトキシリンエ オシン染色管行って CPE 観察した。

接種ウイルス洛各種細胞に接種継代 5 代目以上の Edmonston 株で，それぞれ $10^{3} \mathrm{TCID}_{50}$ のものを使用し
た。

培養波は $20 \%$ 仔牛血清加 YLE 培養液を細胞堌殖用 飞，5\% 仔牛血清加 YLE 培養液を維持用に使い，5日 目ごとに培養液交交換した。

同一細胞の CPE の連続的観察《は，位相差顕微鏡に よる映画撮影声行走い，上記染色標本による所見とを併。 せつつ観察した。

結果：線維芽様細胞牥ウイルス接種後 3-4 日で認め

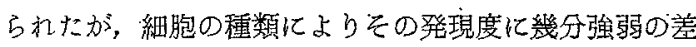
があり，FL 細胞，HeLa 細胞及び JTC-3 細胞では著 明であったが，犬腎細胞ではやや低度であり，八ムス夕 一腎䋖胞ではさらに低度であった。

次に引続き多核巨大細胞の出現が認められたが，時間 的にはいずれの細胞でも同時的であり，ウイルス接種後 平均 3-5 日加始まり，大きいものでは 25 30 個, ‘あ るいは，それ以上の核数走有するもの胲観察された。そ して殆ど全ての細胞に初いて核付近にエオジン赀好性の 細胞質内封入体がみられ，その後少し遅れてウイルス接 種後 7-10日頃加ら, 核内封入体も認められるようにな った。

さらに培養を継続する場合には線維芽様細胞は全く消 失し，全細胞が円形化してきて巨大細胞に於ては多数の 核内封入体を有し細胞中央部に嚓状に集合排列して，そ の周围存大きく成長しだ細胞質内封入体が取り围み，細 胞質を殆ど失った細胞となり，ついには管壁より脱落し ていくの3゙みられ，大体代於てウイルス接理後10日頃 から30日頃迄化わたって行われた。

映画撮影による観察では, 多核巨大細胞の形成は異状 核分裂による結果出現するものではなく, 細胞の融合に より形成されるものであるてとが判った。

(2) Fine structure of filaments in dog kidney cell infected with measles virus. (Virology 亿投稿伸，揭採確定）

麻疹ウイルス感染犬腎細胞の超薄切片による電子顕微 鏡的観察竞行い，核内封入体に爫引れるフィラメント

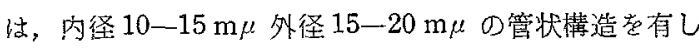
ているととが判った。

(3) Micromorphological changes in dog kidney cells infected with measles virus. (「ウイルス」 亿投稿中，揭採確定）

麻疮ウィルス感染犬嫿細胞学用いて封入体形成過程を 電子顕微鏡的に観察した結果, 形成初期には疎在したつ ィラメントが，形成進行に伴って次第に集合配列してゅ き，横断面范観察した時には，恰もアデノウイルスにみ 
られる如き結晶状にならんだ粒子としてみられた。

現在：麻疹ウイルス；システンパーウイルス及び牛疫 ウイルスを大腎細胞に感染継代するてとが出来るように なったので，との状態に於ける血清学的関連性について 奏験中, 又電子顕微鏡的には, フィラメントとウィルス 粒子との関係它追究中です。

7. 麻跈に関する基礎的研究，麻跈ウイルスの 免疫学的分類及び生物学的性状の比較に関 する基礎的研究

突戸亮

（協力者：河野晴也）

実施内容：麻疹ウイルスの免疫学的分類や生物学的諸 性状の比較を行う目的で，先ずプラック（plaque）法に よるウイルスの定量法の確立やそのプラックの性状等に ついて基礎的研究を行った。

(1) 培養細胞の検討

従来，初代サル腎細胞や HeLa 細胞についてプラッ ク法が行われているが，我々は，アフリカそドリザル継 代株 Vero 細胞が麻疹ウイルスに高い感受性があり且つ プラック形成に適しているととを見出した。重層に用い られた条件は，YLE+2\% 仔牛血清 $+11 \%$ 寒天であ る。之によるとプラック発現までに3〜4日，5６日に 中性紅の染色を行い，12〜20時間にプラック暑数元た。 猶，得られたプラックはモルモット麻疹免疫血清及びヒ トのガンマーグロブリンで完全に中和され，又プラック 数は接種量とよく比例するととが認められ，その特異性 が確認された。

(2) プラック法によるウィルスの增殖の測定

Vero 細胞内での麻疹ウイルス（エドモンストン株） の増殖を追跡した所， moi $=0.1$ でその eclipse は， 18 〜 19 時間，増殖の平衡期は 70 時間で始った。そのとき の感染価は $7 \times 10^{7} / \mathrm{ml}$ PFU に達した。

(3) プラックによる麻疹ウィルスの分類

業室に継代されているエドモンストン株及び豊島株で プラックを形成させて観察してみると両者共に，早期に 発現して大型 $(1.5 \sim 2.5 \mathrm{~mm})$ 真円形のプラックと発現 のやや招そい小型不規則のプラックをつくるてとが分 り，プラックの大きさによって更にてれらの株からいく つかの分枝株 (Substrain) をうるととが出来た。とれ らの分枝株について, その安定性や生物学的諸性状の差 苍現在検討中である。

（4）インターフェロンの研究

Vero 細胞培饗についてインタフェロンの産生を検索
したが，現在までの処インターフェロンの産生を積極的 に支持する成續が得られていない。

\section{得られた結果 :}

（1） プラック法の確立するととによって麻疹ウィル スの定量法が従来の $\mathrm{TCID}_{50}$ ではかる方法より，より正 確になった。

（2）プラックの性状から、現在の継代株は・更にいくつ 加の分枝株に分けられる事が出来，之について今後検討 すべき必要性が生じた。

（3）ウィルスの生物学的性状，例えばその動物に対 する病原性の強さ等をプラック性状からも検討出来る可 能性を提出した。

8. マウス脳親和性はしかウイルスによるマウ ス及びハムスター脳炎の形態学的研究 草野信男

（協力者：青山友三）

前年度報告した如く，吾々は FLで継代を重ねるうち に, 乳のみマウス脳内接種で高率に脳炎を扣てす，はし 加ウィルス変異株を分離し，その感染病理に若干の知見 を得た。今年度はさらに同研究を掘り下げ，乳のみハム スターについて同様の実験を打てなった。

\section{材料及び方法：}

ウイルス：前回同様に上記杉山変異株 (MK6-FL124DEA $\left.1-\mathrm{M}_{17}\right) 10^{3.5} \mathrm{TCD} 50 / 0.1 \mathrm{ml}$ 老 i.c. 一部字 i. p., i. $\mathrm{n}$ 接種

ハムスター: Chinese hamster (Shiihashi) 1〜7日 令の同腹ハムスタ一。

煌光抗体法; 前回同様, サルの感染免疫血清。(CF て 256 倍）その $\gamma$-グロブリン分画に FITC を標識。八厶 スター脳アセトンパウダーで吸収し，4倍稀噃で使用し た。ラベル抗体の特異性は正常八ムスタ一脳，及び他ウ イルス (ヘルペス，日本脳炎，インフルエンザ, HVJ 等) 感染脸の間に扣ける交叉反応处確めた。

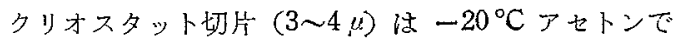
1 時間, 又は $-20^{\circ} \mathrm{C}$ ダイフロンで 1 時間前処理（従来 固定とよばれていた過程）した。後者の方がすぐれてい る。（脳りピッドを除去し抗体水溶液とよく反応する。） ついでラベル抗体 $5^{\circ} \mathrm{C} 15$ 時間反応 (染色)ざせた。

結果：発症，擎死は夫々i.c. 接種後 5 日及び 7 日で， 何れも乳のみマウスの場合に比べ $2 \sim 3$ 日早い。しかし 脳内のウィルス量は $\max$ で同程度 (10 $0^{4.5 ~ 5.0)}$ であっ た。7日令以前では略, 100\% 発症する。

特異螢光は i. c. 接種 1 日後より接種局所の神経細胞 
そみとめられる。2 3 日後より対側半球の皮質神経細 胞, 次いで両側海馬角脳幹神経核等の神経細胞にウイル ス抗原を認めた。マウス同様海馬角は $100 \%$ 陽性にで る。

嗅脳や網膜の神経細胞にもしばしば特異光を認めた が, てれは, マウスに比へ, さらに, 向神経細胞親和性 (neuronotrope) か漒いととを示している。

神経細胞内の抗原分布は, 感染培養細胞のそれに一致 する。すなわち細胞質内に微細顆粒状及び粗大滴状に認 められ，核には全く陰性である。特に後者の性状は狂犬 病ウイルスの神経細胞内に和ける抗原のそれと極めて似 ている。而ウイルスとも・ミタソグループに属すが興味深 い所見である。

它細胞はマウスのときと同様, 主として海馬角で神経 細胞の融合により生ずる。その細胞質にも特異光がみら れる。

脳室上皮, 脳膜, 血管等は何れも陰性，まな小脳，脊
䯣等では神経細胞も陰性であった。 中枢神経系以外の部位仕全く特異光が認められない。

i. p., i. n. 接種では脳的螢光はみられず発症もしない。 現在続行中の実験について :

(1) 螢光抗体法 (FAT) は抗原抗体反応の極为て高い 特異性を利用した手技なので，吾々はさらにその感度を たかめる為，抗体例及び抗原側から再検討をしている。 すでに日本脳炎の感染病理について FAT 老用いた際, 抗体側の問題としてサル免疫血清では $\gamma_{2}$ 分画が最も抗 体量の多いと之を知った。はしか纪ついても同様のてと が考元られ目下その $\gamma_{2}$ 分画にラベル走行っている。ま た抗原側の問題としては切片の前処理が検討され，フロ ロカーボン处理だけでなく, 䣼素処理や超音波处理等党 行って若干のデータ寺得つつある。

(2) 現在サル脸内接種が扣てなわれ, その解析分続け られている。（2月2 日に終了予定） 


\section{8）䳕赤芽球症のウイルス学的研究}

代表者 中 村 稕 治 (日本生物科学研究所所長)

\section{班員および分担研究課題}

1. ウイルス学的研究 (I)

\section{日本生物科学研究所所長}

同所 員

同 所員

2. 感受性ならびそ抵抗性舀系統の育成

名古屋大学, 農学部 近 藤 恭 司

3. ウイルス学的研究 (II)

農林省家畜衛生試験場 清.水武彦

4. 害験小動物感染に関する研究

東京大学教授 (伝研)

\section{研究目的}

舀白血病群ウイルスの研究は，わが国打よび各国の養 舀界に深刻な被害を与えつつある鵎白血病の病原解明上 極めて重要なととであるばかりでなく，一般腫瘍ウイル スの研究にも連らなり,殊にラウス肉腫ウイルス (RSV) との関連打よびその応用など特殊の課題をも含むもので ある。

それにも拘らず現在までのとてろ，ての面の研究は主 としてアメリカに招いてなされ，かが国では殆んど行わ れて扔らず甚しく立遅れている。

さて鶏赤芽球症ウイルス (Avian Erythroblastosis Virus: 以下 $\mathrm{E}_{\mathrm{R}}$ ) R株は Engelbreth-Holm (1932) に よって分離され, Beard ら (1955 1958) によってその 性状が可成り詳細に研究されているEＣの代表的株であ り, 他の鵎白血病群ウイルスすなわち内蔵リンパ腫症 (Visceral Lymphomatosis), 骨䯘芽球症 (Avian Myeloblastosis）にくらべ，比較的速汃に宿主に急性型 の発病を起させる大きな利点がある。

本研究は本株を対象としているが，それは先ずてれよ り入って一般鵎白血病群ウイルス研究の端緒范開くてと の便宜を考慮したからである。

そして本研究の值接目的结先ず第 1 段階として本ウイ ルス定量法の確立と実験動物系の確立をは汃り，次段階 としてその基礎の上にウィルスの諸性状を研究し，感 染, 発病执よび免疫等の諸問題を検討するととにある。

\section{本年度研究成果と今後の計画概略}

野村, 中村, 田島班員に上る日生研の研究は前年度に 引続き，わが国既存のにわとりにつき，品種，系統を異 にするにわとりひなのR株ウイルスに対する感受性の比 較実験を続行したほか，今年は鵎胎児についても同様の 実験を試み，名古屋大近藤班員は特定系統のひな抌よび 有精邲煘受性試験に提供し，選ばれた高感受性系統 (BM-C 系) 扣上び低感受性系統 (NH-N 系, NG-B 系) については近親交配を進めて一層その固定度を增すとと に努力し, 一方血液型の検査や細胞由来 HA による検査 を行なって系統育成上の進度をチェックした。

日生研扣よび名古屋大の今日までの研究結果汃ら凡そ 次のととが結論された。

1.ひな扣よび鵎胎児は R株ウイルスに感染して特異 の変化を起てし，剖検扔よび捺押組織の検查によって容 易に感染方証明される。

2.ひな打よび鵎胎児の感受性は略一致している。

3、ひな抢よび鷄胎児の感受性には, 供試群により著 しい差違があるが, 現在までの調查範团では, 品種扔よ び系統すなわち，遺伝学的な因子が最も支配的な影響を 持っていると見られる。

4. 現在までの経験範囲では特定高感受性系統のひな 扣よび胎児の感受性牥可成り均一でてれいよるウィルス 価測定の可能性が認められた。

日生研扣よび名古屋大の研究結果では，一応ひな扰よ び鷄胎児について遗伝学的な考慮を払うだけで，てれら をR株ウイルスの Assay 汇利用し得る可能性があるよ うな印象が与えられている。しかしながら，わが国鷂に 内臓型淋巴腫症が広く分布するととは公知の事実であ りまたVLウイルスと $\mathrm{E}_{\mathrm{R}}$ ウィルスの間に病原抽よび 抗原関連の存在することは一部研究者の認めるとてろで あり， $E_{R}$ ウイルスのひなを用いる in vivo Assay と打 いても，VLまたは $\mathrm{E}_{\mathrm{R}}$ ウイルスの自然感染の影響を無 視するととには問題がある。

この意味からも或は将来 VLウィルスにまで研究を進 める際の便宜のためにも，また RIF test (Rubin： 1961）の応用による本ウィルス定量法の確立のために 
る, Assay 動物には遗伝学的考慮范払う以加化，少く とも RIF free を証明しておくととが賢明である。

家畜衛生試験場清水班員は主として RIF test 法の確 立に努力し，現在までのとてろ，RIF test の基礎をな すRSV の Assay は鷄胎児の初代培養細胞を用いる限 り，かなり均一な成績をもって成功しているが，その 2 代以下の継代培養では細胞を良好な状態で維持するてと が困難で完全な形で RIF test 䒠施できる段階に至。 ていない。（改良の要点として添加牛血清を検討中であ る)。

伝染病研究所田嶋班員は，本ウイルスの実験小哺乳動 物感染の検討に供すべく，近交系マウス (12 系統)，八 ムスター（３系統）の兄姝交配に上る育成を進め，その 一部マウスについて感染実験を試みたが, 腫煌発生蚛陰 性に了っている。

本班今後の研究課題として次の各項を予定している が，それらの一部については現在すでに進行中である。

i）感受性支配に対する遺伝学的背景の一層の検討在

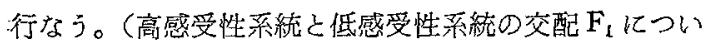
ての感受性を検討する)。

ii） CF, VN test の確立在目指し，先ず適当な材料 を選んでウィルスの精製を行ない，てれによるにわと り，または哺乳動物の免疫血清の作製若行ない，両 test 法の樹立をは加る。

iii）本ウイルス感染宿主細胞の形態学的研究を開始す 3。

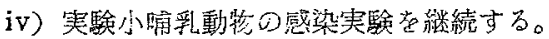

v) RIF test の諸条件の検討, RIF free ならびに特 定系統の実験動物としての確立に着手する。

1. ウイルス学的研究 (I)

中村䅧治, 野村吉利, 田島正典

研究目的：品種，系統を巽にするにわとり，ひななら びに鷄胎览の鷄赤芽球症ウイルス $\mathrm{R}$ 株に対する感受性の 比較を行ない，遺忶的に比較的固定した感受系統の探 索，発見に努力，てれらのひな，鵴胎児を用いる本ウィ ルス定量法に役立てる。

\section{本年度の成果：}

1）ひなとついては前年と全く同一様式すなわち，生 後10〜12 日にストックウイルス（感染ひな脾，肝谏結 組織) の 10 倍階段稀䣋 $0.1 \mathrm{mI}$ を心臟内接種して特異死 〔脾，腎の腫大，赤変，肝塗抹に打ける赤芽球の証明)の 起り方を観察（約 1 力月間）し， $50 \% \mathrm{LD}_{50}$ を算出する 方法に上り，

$$
\begin{aligned}
& \text { 卵用種 BM-C (名大) ………1 近交系 }
\end{aligned}
$$

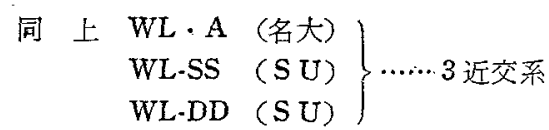

$$
\begin{aligned}
& \text { 同上 } \left.\begin{array}{rl}
\text { WL-SD } & (\mathrm{S} \mathrm{U}) \\
\mathrm{WL}-\mathrm{DS} & (\mathrm{S} \mathrm{U})
\end{array}\right\} \cdots \cdots \cdots . \mathrm{WL} 2 \text { 近交系の正 } \\
& \left.\begin{array}{lll}
\text { 兼用種 } & \mathrm{NH}-\mathrm{N} & \text { (名大) } \\
& \mathrm{NG}-\mathrm{B} & \text { (名大) }
\end{array}\right\} \cdots . . .2 \text { 近交系 }
\end{aligned}
$$

合計 8 群の感受性を絽返し实験によって比較してみたが 昨年の傾向と完全に一致し, 卵用種近交系预よび $\mathrm{F}$ : 群 はいずれも高い感受性を示した $\left(-\log L D_{50} / 0.1 \mathrm{ml}\right.$ : 3.6 4.6) のに対し，兼用種 2 系はいずれも感受性が極 めて低加った $\left(-\log L D_{50}: 1.7 \sim 2.3\right)$ 。

2）鵎胎児としては，ひなに括いて感受性の高功った WL-G, WL-A, WL-DS, WL-SD, BM-C の 5 群と感受 性の低加った WL-B, NH-N の 2 群を供試（各群 2 回以 上の繰返し実験）し，7日畉にウィルス階段稀橎 $0.2 \mathrm{ml}$ を尿腔内接種し，10日～11日後に殺して特異病変（ひ なと同様）を観察し， $50 \% \mathrm{ID}_{50}$ 老算出して感受性支比 較してみたが, 前 5 群は，いずれも高い感受性を示した のに対し，後 2 群の胎児には全く感染が認められず，感 受，担抗雨群の感受性はひなに打ける之同一傾向でその 差は一層著しく表現された。例えば1実験（Exp 6)で， WL-G，WL-SD，WL-DS がそれぞれ 5.2，5.2，5.5の $\mathrm{ID}_{50} / 0.2 \mathrm{ml}$ を示したのに対し, WL-B は $10^{-1}$ の原液で も全く病変を発生しなかった。

3) な扰 WL-B，-G，-SDの3系について10日ビ ナの感受性と 7 日甈の感受性を比較してみたが，ひなに 扣ける $L_{50}$ と畉に扣ける $I_{50}$ (尿照内接種) は殆んど 同一レベルで古った。しの事実加ら発育卵もまたひなに 代わり，本ウイルスのウイルス価測定汇利用される可能 性が認められた。

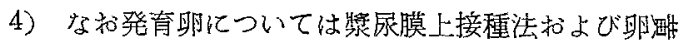

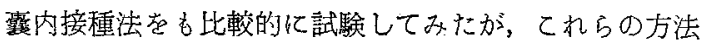
では明らかに感染率が低かった。

発表：本年度の成果の一部は下記に発表した。

野村吉利，中村稕治，近藤恭司：品種系統を異にする 鵎ひなの舀赤芽球症ウイルス R-Strain に対する感受性 の比較. 第12 回日本ウイルス学会総会 (1964. 11)

2. 鶏の赤芽球症に対する感受性系統，抵抗性 系統の育成

近藤恭司

研究目的：鷄の赤芽球症に対し感受性の異なる近交系 
の分離育成を行ない，鵎の実験動物としての確立をはか るとともに，赤芽球症に対する感受性の遗伝学的研究を 行なう。

\section{本年度の成果：}

舀赤芽球定のウイルス感染俉対し，ブラックミノルカ 種 $(B M \cdot C$ 系) は高い感受性を示し, し加も比較的優れ た均一性が認められ，ナゴヤ種 (NG-B 系)，ニューハム プシャ一種 (NH-N 系) は本ウィルスに対して低い感受 性であったので，それぞれ近親交配夿行なって固定度を 高めた。しかし一部化近親交配尤る弱化があらわれ始 めた為, 計画した程の近交係数の上界はみられなか。 た。成鷂のラィトの近交係数は，BM-C系で $39 \%$, NGB 系で 47\%，NH-N 系で13\%であった。な扣赫芽球症 の研究に用いた雛出，上記の次の世代となる為，いずれ ま $10 \%$ 内外上具している筈である。

近親交配に上って種々の遺伝子の固定苍はかると共 亿，前年比つついて血液型の固定热はかる交配方式老と った。交配に用いたものの血液型は，NG-B 系では BQ 型のみ， BM-C 系では $\mathrm{AQ}$ 型， $\mathrm{APQR}$ 型，NH-N 系で は，EGHQ 型，EGHQR 型で市った。本年とれらの子 についてしらべたが，用いた抗血清仙，抗A及び抗Qで ある。抗A沉つては BMC 系は 95\% + (23.习习/24 羽), NG-B 系恃全例 - (26 羽), NH-N 系手全例 - (10 羽) で 西り，抗Q仁ついては，3系とも100\%十であった。

標準抗盘清㹥, 多量に作製するてとが困難であり, 従 って長年月恒久的化使用し難い。また同種免疫によって 作製するものであるから，ウイルス感染性との関連も考 えにくいので次の血球凝集反応を併用した。すなわち培 養 L細胞竞トリプシン処理するてとによって，鵎血球 を凝集する 2 種類 (heat labile $と$ heat stable) の Hemagglutinin ( $\mathrm{HA}_{\mathrm{A}}$ )が得亏れる。しれは飽和 $50 \%$ $\left(\mathrm{NH}_{4}\right)_{2} \mathrm{SO}_{4}$ 溶液で沈澱し, 有機溶媒に溶けることから リポ蛋白と考光られ，恒久的に作製し得るし，てれの示 す㠜集反応は，L細胞にワクチニヤウイルス感染によ。 て得られる HA の篤血球に対する凝集性と同一の態度で ある。との HA 起用いて上記の系統扔上び他の非近交の 鵎沉ついて反忘堂しらべたとてろ, 非近交の白色レグホ ーン、ロードアイランドレッド, コーニッシュについて は, 同一品種内に扰いても $\mathrm{HA}^{+}$と $\mathrm{HA}^{-}$が混在していた が, BM-C 系で怯全例 $\mathrm{HA}^{-}, \mathrm{NG}-\mathrm{B}$ 系は全例 $\mathrm{HA}^{+}, \mathrm{NH}$ $\mathrm{N}$ 系も全例 $\mathrm{HA}^{-}$であった。

すなわち血液型，及び HAによるテストでは，系統育 成上の進歩がるえれ。

な打赤芽球症の感受性の遗伝的研究のために行った
BM-C 系と，NH-N 系の交配は，受精率低く十分な材料 を用意出来ず，結果が得られなかった。

\section{3. ウイルス学的研究 (II)}

清水武彦

研究目的：鷄赤芽球症ウイルスの信頼性ある定量法の 確立。

\section{本年度の成果：}

現在わが国に扔ける鶏赤芽球䆙をはじめとする白血病 群ウイルスの研究の大きな困難は，とのウイルスに全く 感染していない感受性宿主が得がたく，しかうてのウイ ルスの有力な in vitro assay の方法である RIF テスト の条件が複雑で再現性に沉いとてである。そとでま ず，とのウィルスに感受性の高い一系統の鵎群（かなり 高率に䳕白血病に感染している）を飼養維持し，それに 由来する発育畉加ら細胞培養苍つくって，RIFテストの 諸条件党検討する之同時に，ての方法を用いてウイルス 排泄鵎范除去しウイルスフリーの鷄群をつくりだすとと を計面しだ。

RIFテストはRous 肉腫ウイルスの定量を基礎として

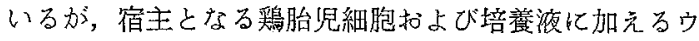
シ血清を選択すれば，あまりふれのないRous 肉腫ウイ ルスの感染洒がえられ，したがってその中和抗体の測定 も可能となった。

RIF テストを完全に実施するには，舀胎児細胞を 3〜 4 日打き亿継代培養して長期間良好な状態に維持しなけ ればならない方，現在までの成績では，2３代までは此 較的困難なしに継代培養できたが，4代以後になると細 胞の增殖性が扣とろえ，ての細胞では Rous肉腫ウイル スの assay ができなくなる。その原因が細胞側にある のか，培養液の側伛あるのか検討中である。

一方, 飼養中の 40 羽のめんぞりのうち, Rous 肉腫ウ イルスに対する中和抗体陽性の10 羽（てのうち 6 羽は， 後亿しらべた結果 RIF テスト陽性の卵をうんでいる) 袁選び，乙れらに由来する卵加ら 48 羽の七ナを捊化し て，注意深く隔離して飼育したが，ての群にな扔かなり 白血病の発生加認为引れ，抗体陽性舀の中にもかなり卵 ヘウイルスを排出するものがあるとと走示㖫した。

\section{4. 実験小動物感染に関する研究}

\section{田鵢 嘉 雄}

（協力者：鈴木 潔，奥木 実，野村吉利） 研究目的：鷄由来のラウス肉腫ウイルス (RSV：S-R

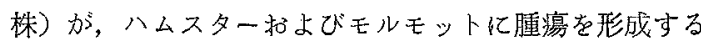


ととはすでに Ahlstrom ら (1962) ほよって明らかに されているが，RSV と抗原的に密接な関連存有する鵎 白血病ウイルスの哺乳動物感染ば未だ報じられていな い。本分担研究は鵎赤芽球症ウイルス $\mathrm{R}$ 株について実験 小哺乳動物感染の有無を検討するとと若目的とする。

\section{本年度の成果 :}

1) weaning マウス-DDD (25日令)，ならびに suckling マウス-Silver (5〜7日令) 2 群に，それぞれ $\mathrm{R}$ 株濃厚ウイルス液を脳内, 皮下, 腹腔内の 3 経路別に
接種し，長期閒観察（約 4 力月）を行なったが，ての実 験範困では腫瘍発現はすべて陰性に了った。

2) 他䎲近交系マウス 9 系統 (A, BALB/c, CF \#1, $\mathrm{CFW}, \mathrm{C} 57 \mathrm{BL} / 6$, DBA, fm, NC, KK); ハムスター 3 系統 (APG，APA，Albino）について兄妹交配によ る䏍成走試み，順次感染実験に供する態勢を整えるとと もに，その他のけつ䨑類すなわち八タネズミ，スナネズ 乏, コットンラットなどについても育成に努めた。 


\title{
（9）植物ウイルス粘子並びに感染細胞組織に関する研究
}

\author{
代表者 日 高 醇 (九大農学部教授)
}

\section{班員および分担研究課題}

1. ウィルス粒子の再傋成之その増殖ならびに寄主の 選択性 京大農学部教授 赤井重恭

2. 植物ウイルスの核酸江関する分子生物学的研究 京大ウイルス研助教授 川出由已

3. タバコモザイクウイルス蛋白質の生化学的研究

阪大蛋白研教授 成田 耕造

4. 宿主細胞内和䏚る turnip mosaic virus ordinary strain の形態

名大農学部教授 平井篤造

5. キゥリモザイクウイルスの純化とその血清学的研 究秦野たばて試研究員 桐山清

6. ウイルス感染細胞の生理礼よび形態的変化

東北大農学部教授 三沢 正 生

7. キウリモザイクウイルスの構造と生物活性

東北大農学部教授 志村 憲助

8. 植物ウイルスの感染を細胞内に扣けるウイルスの 形成

北大農学部教授 村山大記

9. 植物ウイルスの粒子構成に関する研究

阪大微研教授 深井孝之助

10. ウイルス感染組織の生化学的変化

山口大農学部教授 湯川敬 夫

11. タバコモザイクウイルスの接種葉に扔けるる初期の 增殖

九大農学部教授 日高 醇

研究の目的：植物ウイルス群と動物ウイルス群との間 そは，画然とした差が屴って，明らかに類別できるもの とされてきたが，形態的にも化学的にも，その根拠を見 出しがたくなっている。むしろ両者を 1 群として，その なかで他の生物の分類形式と同様に，ウイルスの分類は その形態を第 1 義として，化学成分，増殖法，伝搬，血 清反応，病徴など范参考にした形式を基礎にするのが適 当であ万う。それには，現在ではウイルスに関する研究 業績の蓄積が少なく、いまだその緒についたにすぎない 状態であろう。しかしタバコモザイクウイルス (TMV) では，そのなかの系統類別さえ TMV 蛋白のアミノ酸組 成から可能にされて㕲り，細菌の分類よりも確かな基礎
が得られる希望がある。ウイルス学の研究は, 植物学, 動物学, 農学, 医学山もち万ん, 分子生物学, 血清学, 化学, 物理学などの専門学者の協力扣よびその長年の研 究の結果老必要とする加ら，な和途は遠い加も知れな い。本班は植物ウイルスの粒子の形態，アミノ酸組成な どの諸性質を研究し，さらにその感染細胞組織について の解明を主なる目的として，各方面の専門家を糾合して 協力関係を強力にし, 前記の研究業績の蓄積をはかり, 研究基盤を拡げ，それを堅固な組織的なものにするとと を目的としている。本班としての個々の班員の分担課題 についてはもちろん，其通の基礎をもつととによって， 協力関係を緊密にするために，3 年計画をもって，初年 度の昭和 38 年度にはウイルスの精製純化, 昭和 39 年度 には定量を主題とした研究の基盤を考光，本班の事業と して，本班員学主に他加らそれぞれの尃門学者の参加 の上でシンポシウウム開催した。来年度は感染を主題と する予定である。そして班会議と同時にそれに関するシ ンポジウムの開催考慮している。かくして，精製純 化, 定量, 感染の三うの基本問題を共通基盤として, 本 班の主題の目的の研究を遂行しようとしている。

1. ウイルス粒子の再構成とその増殖ならびに 寄主の選択性

赤井重恭

前年度の報告書に継続して，宿主選択性の解明を目的 とするTMV のカラムクロマトグラフによる分画と；再 構成を解析するための紫外線による不活性化とについて 得た知見を報告する。

1. TMV 分画の感染性 DEAE-セルローズカラムを 供用して得た $0.8 \mathrm{M}-\mathrm{A}, 1.0 \mathrm{M} ; 1.6 \mathrm{M}$ 各分画扣よび末分 画 TMV をブライトイエローに接種し，增殖後にブタ， 一ル・クロロホルム法でTMVを回収し再分画した。 $0.8 \mathrm{M}-\mathrm{A}$ 分画接種区加方回收した TMV は $0.8 \mathrm{M}-\mathrm{B}$ 分画 が認められず $1.6 \mathrm{M}$ 分画が多い。 $1.0 \mathrm{M}$ 分画の感染性仙 極めて低く分画所要量を回収できながった。 $1.6 \mathrm{M}$ 分画 接種区の TMV は，未分画 TMV 接種区に類似した分 画パターンを示したが, $0.8 \mathrm{M}-\mathrm{B}$ 分画が多く, $1.0 \mathrm{M}$ 分 
画が少ない点で相違か認められる。未分画接種源 TMV の分画パターンは $0.5 \mathrm{M}$ 分画が少なく $0.8 \mathrm{M}$ 分画が多い てとによって，てれらの諸パターンとは区別されるが， $0.5 \mathrm{M}$ 分画は大部分が超遠心法で除去されるものと考光 る。てれら分画パターンの相違が，すでに報告した如 く，单なる粒子の集合と解離によるもの加否汃は後検 討する。

2. 紫外線によるウイル又不活性化機棈 TMV-RNA 打よび SRNA に紫外線老照射すると，240２80 m $\mu$ の 波長域での吸取低下が認められるが，ての低下の程度は 温度, 線量によって異なる。乙の吸収低下は $8 \mathrm{M}$ 尿素処 理によって，完全回復されないととから単なる励起分子 の会合に基づくとは考壳引れない。SRNA に照射した場 合に尿素処理による hyperchromic effect は增大する が，ホルムアルデヒド反応には著しい変化を認めていな い。TMV-RNA の場合には尿素処理による hyperchromic effectは，照射上ってむしろ減少し，ホルムア ルデヒド反応も減少の傾向にある。てれらの結果加ら TMV-RNA と SRNA 訬紫外線比対して異子る反応を示 し，それが in vitro に扣ける分子構造のちがいに基づ くものと考元られ，TMV-RNAの場合はは部分的二重 鎖の固定があるものと仮定している。

\section{2. 植物ウイルス核酸の分子生物学的研究} 师出由已

（1）イネ萎縮病ウイルス捛よびその RNAの物理化学 的性質の研究，(2) ウィル之核酸に上る感染が任意の細 胞で成立し得るか否かを調べる。

（1）部分精製されたイネ菱縮病ウイルス材料について 沈降測定を行ない，レオウイルス，wound tumor ウイ

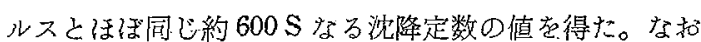
若干の非ウイルズ成分が認められたので，高度精製法を 検討した。（2）の目的に対しまず実験の容易な系とし て，大腸菌ファーシ MS 2 の RNA と種々の“非感受 性”細菌のプロトプラスト，同 RNA と動物細胞，小型 20 面体動物门ィルス（ECHO 7）RNA と細菌プロトナ ラストとい.う組合わせを選び，扔の扰の RNA 感染によ って成熟ウイルス産生があるか否が調べた。そのうち ファージ MS 2 が非天然宿主たる Bacillus megaterium でよい増殖するてとが見出された他は陰性の結果であっ た。他に棒状植物ウィルス (TMV) RNA一動物細胞など の系についても実験を開始している。

発表：川出由己・深田哲夫：細菌“プロトプラスト” ヘのバクテリオファーシ RNA の感染，第37回生化学会
総会 (生化学, 36, 627, 1964).

川出由己：ウイルス RNA といわゆる非感受性細胞と の相互作用, ウィルス学の進展, 1964, 京大ウ.イルス研 シンポシウム記録，p. 107-114.

3. タバコモザイクウイルス蛋白質の生化学的 研究

成田耕造

（協力者：次田 睈）

（1）タバコモザイクウイルスのアセテル末端の生合成 機作を明らかにする。(2) 人工的化変異株觉作る特異的 方法の検討。(3) 日本のタバコモザイクウイルス蛋白質 の化学組成, 以上の 3 点を今年度の研究目標とした。

(1) 昨年度に引き続き蛋白質のア七チル末端基けつい て検討した。醀酸が活性化され s-RNA 亿取込まれる系 は存在せず，またアセチルアミノ酸では，2，3のアるノ 酸については大腸菌，ネズミの肝臓の無細胞系の実験で は活性化されているように見られた。しかし s-RNA のアセチルアそノ酸の取込みは現在きで見られなかっ た。以上のととは用いた s-RNAにアセチルアミノ酸草 取り込む能力がないとと范示㖫し，また肝葴の系では見 出されたアセテルアミノ酸が，生体内に存在するアミラ 一ゼによりアるノ酸となって活性化されるととが証明さ れている。てれらのてと蛙，アセチルア之ノ酸の活性化 酵素が存在しないのではないかというととをも示惨して

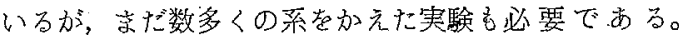
(2) 业硝酸㹥タバコモザイクウイルスの RNA 中のシト シンをウラシルに変化させ，高頻度で変異株を作る。て のととは次田らによって遺伝情報の研究に利用されてい ることが報告されたかう，ての度ば゙ィタミン $\mathrm{B}_{2}$ の溶液 中での光酸化反応が変異株を作るのに有用ではないふと いう䂓点汃ら研究が進められた。ての反応によって起る 変化がグァニンの消失のみ，起すてと㒻出し，またそ の失活は 1 次反応であるてと范ウィルス及びその RNA について見出しだ。い宗のとてう，変異株見出されて いない。(3) 予備的な実験の結果ではわが国の夕バコモ ザイクウイルス蛋白質のアミノ酸はバークンー，チュー ビンゲンのそのウイルス蛋白質のアミノ酸組成とは 2,3 . のアミノ酸については一致しないととから，さらに詳し いアミノ酸組成を, 温度による可逆的な変翼現象と照し 合わせて研究を進める積りである。 
4. 宿主細胞内に括ける turnip mosaic virus ordinary strain の形態

\section{平井篤造}

(㙝力者：松并千秋）

アブラナ科植物のモザイク病は世界各地に分布し，本 邦に扎いても疏菜溨培上の重要病害である。turnip mosaic virus はとのモザイク病の最も重要な病原ウイ ルスの一つであり, 吉井甫住, 宿主範困よりてれ㟲 ordinary strain と cabbage strain とにわけ，前者の 起原学東洋仁もとめている。栃原比吕志方分離した $\mathrm{P}$ 分 離株と $\mathrm{R}$ 分離株とは，いずれもその宿主範田よりみて， ordinary strain の代表的分離株であって，两株纯血清 学的に近緣関係にあるという。とてろが，P分離株の精 製試料が常に約 $13 \times 700 \mathrm{~m} \mu$ の紐状粒子上りなると反 ᄂ， $\mathrm{R}$ 分離株では約 $13 \mathrm{~m} \mu$ の球状粒子が主でありり，その なか代約 $13 \times 700 \mathrm{~m} \mu$ の紐状粒子が少量混在し，しか子 $\mathrm{R}$ 分離株精製試料の感染性は $\mathrm{P}$ 分離株のそれよりもはる が低い。とのように形態の全く異なるウィルス粒子相 互が，姐清学的に近縁関係仙あるととは奇異なととであ って，R分離株精製試料怘構成す号球状粒子は紐状粒子 の切断に由来するとの疑なしとしない。本研究は， turnip mosaic virus ordinary strain $\mathrm{R}$ 分離株精製 試料にみられる球状粒子方宿主細胞内に存在するか否加 を確めるために行なっだものである。

$\mathrm{P}$ 分離株を接種した Brassica rapa $\mathrm{L}$. と R 分離株を” 接種したPetunia hybrida VILM. とをそれぞれオスミ ウム酸で固定し, その後, 常法により超薄切片を作り, 電子影徴鏡下で宿主細胞内のウイルス粒子を観察した。 同分離株をもに，ウイルス粒子は細胞内では集団をなし て細胞質内のみに存在している。てれらのウィルス粒子 集固中，最もしばしば観察されるものは，個々の紐状粒 子が束状に密に集合したものであり，ついで環状また は，口ゼット状集合した紐状粒子の集团が見ら能た。 また，両分離株間で紐状粒子集団の出現頻度に峙全く善 異が浔好られず， R分離株の感染細胞でみられる紐状粒 子は約 $12 \times 700 \mathrm{~m} \mu$ であり, 球状ウイルス椂の粒子は全 く検出できなかった。したがって，R分離株精製試料を 構成する 12 13 m $\mu$ の球状粒子は，紐状粒子が精製過程 で細切されたものであり， R分離株本来の形態は $\mathrm{P}$ 分離 株粒子と同様に 12 13 $\mathrm{m} \mu \times 650 \sim 700 \mathrm{~m} \mu$ の紐状であ ると結論される。また， R 分離株精製試料の感染性の低 下は，紐状ウイルス粒子の切断に由来するものと考える のが妥当であろう。
5．キウリモザイクウイルスの精製と形態 桐山清

キウリモザイクウィルス (CMV) の普通系 (CMV-

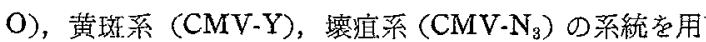
いて，分画遠心と密度勾配遠心とにより，精製を行な い, CMV 粒子の電子顕微鏡観察を行なった。

1. 分画遠心試料

分画遠心で精製した CMV-Y は高い病原性があり，ま た再現性も高い。てれに反して CMV-O, CMV-N は収 量が低く，活性の回收仙 CMV.Y D 1/2 1/10 で西っ た。精製試料仿硼酸緩衝液（pH.9.0）で $0 \sim 5^{\circ} \mathrm{C}$ 亿保存 したとき，数力月間，活性を保持した。 CMV-Y の 1 例 では，138 日後，10 倍稀勫で 194 個の斑点を生じ，最初 の $1 / 10$ 程度の活性を保っだ。

\section{2. 密度勾配遠心試料}

分画遠心した CMV 党 Brakke の方法に従って密度 勾配遠心苍行なった。Spinco 遠心機 SW-39 rotor によ る遠心では，上部より $3.4 \sim 3.7 \mathrm{~mm}$ の位置に $3 \mathrm{~mm}$ 巾の 一つのバンドが観察された。カラムの底に究ああ 5 滴 ずつ分画し，UV 吸収を測定した結果，バンドを形成し た位置が，ODも最高で尚った。 Spinco 遠心機 SW25.2 rotor で 240 分遠心した結果, 上部より $5.1 \mathrm{~cm}$ の位

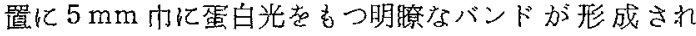
た。この部分を取出し，UV 吸収执よび病原性を測定し た結果, 病原性の大部分はバンドの部分に集約され, 単. 位 $\mathrm{OD}$ 当りの病原性は，バンドの方が高く，精製度の高 いととを示しだ。

\section{3. 電子顕微鏡认上る観察}

精製した CMVのO，Y，Nの3 系統をPTA 染色を 行ない電顕観察を行なった結果， 3 系統とも形態的の差 は認められなかった。CMV 粒子の大きさは 28〜30 mpt で，多数の突起が，粒子の表面に観察された。CMV-O と CMV-N とは，保存により崩壊したと思われる像が多 数見られた。CMV 粒子の capsomere の数，その他の 詳細纪ついて，検討中である。

6. ウイルス感染細胞の生理和よび形態的変化 三 沢正生

植物ウィルスの感染扔よび感染細胞内でのウィルスの 增加機構を解明する目的で, 感染細胞・健全細胞の生理 - 形態的変化の比較対照研究を行なっている。昭和 39 年度は主として感染に伴う核の状態について実験し，ま た葉組織内の感染細胞の堌加経過と感染細胞の内部形態 の変化老明らかにしようとした。 
CMV の感染過程执よび感染細胞の生理異常と CMV. 増加との関連について, 引続き実験した。 CMV は剝離 されだササゲの表皮細胞では bio-assayによる限り増加 が諗められない。．しかしタバコの表皮細胞では增加す る。また感染に際し，タバコ葉では，必ずしも表皮細胞 苍経由する必要はないが，ササゲ葉では葉肉細胞に CMV を直接接種した場合には病斑が生ぜず，CMVRNA の場合には病斑が生ずる。要するにササゲ葉が CMV に感染する場合，表皮細胞が CMV の増加過程に 特殊の役割を持っているのではないかと思われる。ずな $わ ち$ local lesion host $己$ systemic infection host その表皮細胞は，感染に引続く CMV の増加に対し役割 を異にする印象を受ける。

CMV 感染細胞の核は, 感染 4 時間後ヒストン含量が 增加し 12 時間後減少して, 健全核と同じレベルに復帰 する。とのヒストンは DNA と結合しているものであ る。核の全蛋白含量は，感染による変化が認められない ので, 非ヒストン蛋白の合成は感染により一時的に抑制 されるのであろう。ヒストン合成の変化住，核内 DNA の消長と一致している。とストンの堌加は, RNA ポリ メラーゼ执よび RNA の制御と関連しているものと思わ れる。

タバコ葉には, 最適 $\mathrm{pH} 7.0$ と 5.0 の 2 種の RNase がある。これらの酵素の活性は，感染により異なった影 響を受ける。 pH 5.0 .の酵素のみが影響され, 感染後 3 時間の間は活性が低下するが，4時間以後は逆に増大す る。との現象は，105,000 g上澄打よびクロロプラスト分 画で著しく，マイクロソーム・ミトコンドリヤ分画では 健全葉と大差がない。

7.キウリモザイクウイルスの構造と生物活性 志村䍢助

本年度も前年の研究に引続き精製ウイルスを収量よく 得る方法についてさらに検討した。現在むでに得られた 結果を要約すると次のようである。

本農学部三沢研究室にて調製した CMV 感染タバコ葉 の葉肉部分を集め蒸溜水で洗涤後， $0.1 \%$ シテイン， $0.1 \%$ シスチンを含むクエン酸緩衛液（pH 6.8）を供試 タバコ葉を同重量加え, Waring blender で冷却しつつ 3 分間磿确し，ガーゼ濾過で㩁汁を得た。有機溶媒とし てnーブタノール，クロロホルム，ジクロロメタンを比 較した結果ジクロロメタン添加がもっとも良好で，無添 加搾汁に比し 3～10 倍のウイルス活性を認めた。

上の搾汁を $1,800 \times \mathrm{g}, 10$ 分間遠心分離し，上澄液を
0.05\% システイン， $0.05 \%$ シスチンを含む蒸溜水に対し て $0^{\circ} \mathrm{C}$ で 2 時間透析, さらに同濃度のシステイン及びシ スチンを含む $0.05 \mathrm{M}$ 嗍酸緩衝液（ $\mathrm{pH} \mathrm{9.0）で} 12$ 時間透 析した。この際 CMV の失活苍防止する目的で $0.01 \%$ 濃 度のゼラチンの添加が有効であっだ。また上記 $1,800 \times \mathrm{g}$ 遠心の沈激区分をペクチナーゼで処理すると，吸着して いた CMV が可溶化し CMVの収量が約 2 倍に增加する とと䕀認めた。

透析液老 $5,800 \times \mathrm{g}, 10$ 分間遠心，上澄液をさらに $105,000 \times \mathrm{g}, 90$ 分間遠心，得た沈澱を $0.005 \mathrm{M}$ 䃆酸緩衝 液 $\mathrm{pH} 9.0$ 亿䀣䀜して部分精製 CMV 試料とした。こて までのウイルス活性, 収量は. $43 \%$ であった。試料の電 子顕微鏡図は可成り均一な球状りイルスを認めたがな 和不純物の夾雑が見られた。

さらにイオン交撸セルロースカラムクロマトグラフィ 一による精製を種々試みたが，七ルロース系の樹脂には CMV は極めて強く吸着され回收率が著しく低かった。 目下セファデイクス系により精製范試みているが， $\mathrm{CMV}$ がセルロースに強く吸着される事実加ら，逆に CMV の特異的精製法として利用しうる可能性も考えら れる。

8. 植物ウイルスの感染と細胞内に拓けるウイ ルスの形成

村山大記

ウイルス感染植物細胞内に初けるウイルスの形成をウ イルスと植物との組合せを変えて溃光抗体法にて追跡す る。ジャガイモ葉巻病ウイルス怯その性状に不明な点が 多く，細胞内に初けるその形成などは明らかでない。乙 れがためまずウイルスの精製を行ない，之の諸性状を明 らか比する。

TMV-0 亲と为ムスン, PVX-5 系とサムスンの組合 せで病徽とウイルスの分布とについて溃光抗体法による 組織学的研究を行なった。PVX-5 系はサムスンの葉面 に輪紋または曲線状の細胞壊死带学現わすが，乙の部分 の細胞は完全に乾枯し，局部壇死斑内の細胞死々同様の

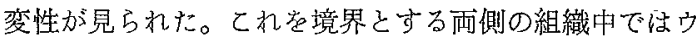
イルス抗原にやや量的の差が認められる場合がある。輪 紋の出現とウイルス增殖細胞の分布に何らかの関連性が あるようである。TMV-0 系化よる病徵は濃緑色と淡緑 色の部分からなるモザイクであるが，てのうち淡緑色の 部分からは強い篮光が見られ，ウイルス抗原量が多かっ たが，濃緑色の部分からはほとんど螢光が見られず，と くに島状の濃緑色部ではまったくウィルス抗原を検出で 
きなかった。ジャガイモ葉巻病ウイルスの精製は次のよ う行行なった。罹病 Physalis floridana 觉 DIECA 老添 加して磨破し，クロロホルム・nーブタノールで処理した 後分画裳心以よって清澄な試料学得た。その試料の活性 を調ベたととろ陽性の結果が得られた。一方その試料の 紫外部吸收測定したとてろ $260 \mathrm{~m} \mu$ 亿極大, $240 \mathrm{~m} \mu$ に 極小をも核蛋白質ようの吸収曲線が得られた。しかし 健全植物汁液でも吸光度は低いが同傾向の吸収曲線が得 られた。このととからウイルス濃度がかなり低く，かな り植物成分が残存しているととがうかがわれた。さらに クロロホルム・nーブタノール法により得られた試料を DEAE-cellulose column にかけ, 食塩溶液 $(0.1-1 \mathrm{M})$ で step-wise で溶出したとてろ，0.6 M 区に $\mathrm{OD}_{260}$ の最

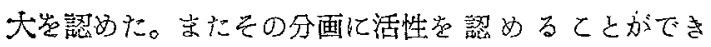
オ゙。しかし健全区に扣いても $0.6 \mathrm{M}$ 区に最大の吸光度を もつ同傾向のものが得られたので，目下 linear gradient elution を行ない実験継続中である。

発表：村山大記・小島 誠：ジャガイモ葉巻病ウイル スの精製 (予報). 日本植物病理学会北海道部会で講演し た。 1964 年 11 月 4 日。

\section{9. 植物ウイルスの粒子構成に関する研究}

梁并孝之助

(協力者：保坂康弘）

イネ萎縮病ウイルスの粒子形態を明らかにし，このウ イルスに扔ける粒子内での核酸の存在のしかたを明らか にしようとした。

イネ萎縮病ウイルスの電顕的研究によって，てれがは ぼ正 20 面体型ウイルスであることは明らかにしえたが， な招その蛋白カプシッドの微細棈造は明らかにはできな かった。それで Markham 等によって提案された rotation technique 倠当研究室に扣いて開発し，てれをイ ネ萎縮病ウイルスに適用したとてろ，てのウィルス怔 20 面体をとるととが確実に証明された。しかし，1筒 1 箇のカプソメアの構造は，何故か，明確ではない。種々 の酥素処理を行なった結果から考えると，ての妨害は， リピドあるいはリポプロテインの混在によるものである らしいが，その本質はまだ明らかであるとはいえはい。 カプソメアが円柱状であろうととは推定できるが，そ の微細構造を明らかにするには至らないので, 分担者等 の作業仮説である粒子頂点が, 感染纪際しての核酸放出 関係がある，という考えは展開するてとができなかっ た。

現在人工的な核酸放出，粒子内に扣ける核酸の局在箇
所, core の構造等を電子顕微鏡によって系統的に研究 しつつあるが，材料を得るととに難点があるのと，分解 能の不足のために研究の進度ば思う程仙は性加どらなか った。

10. ウイルス感染組織の生化学的変化

湯川敬夫

ウイルス感染後の植物体組織の呼吸量の変化の測定を 前年に引続いて行なった。ウイルスには TMV を用い， 植物にはタバコ（品種ブライトエロー）觉用いて，接種 後1日〜10日まで, 24 時間每に測定し，その変化を求 めた。

測定方法：全身症の呼吸測定であるがら，均一な個体 を選び，個体数之測定回数之艺多くして誤差を少なくす るようつとめた。温室内で栽培した6〜8葉期のタバコ 鈄約 100 個觉，健 $(\mathrm{H})$, 病（I） 2 区に分けて，(I) 区に はTMV 霍病汁液を，(H) 区にも健全汁液をカーボラン ダムを用いて汁液接種を行ない, 直ちにてれらの処理葉 をコルクボーラーで一定数打抜き，常法によりワールブ ルグ検压計により 1 時間測定，それぞれ $\mathrm{QO}_{2}(\mathrm{I}), \mathrm{QO}_{2}$ $(\mathrm{H})$ 老得, 生重比として, 健·病の呼吸比 $(\mathrm{I} / \mathrm{H}$ 呼吸比) を求めた。接種後 24 時間毎に，接種葉加引同様武料总 打抜き10日間の同比期線を求めた。ま汇同時に同一葉 片ッンプル党ウイルス濃度定量用に用い, インゲン半葉 法により定量した。

測定結果：7月 20 日接種区，10月 13 日接種区，12月 9 日接種区の各 3 回とも比較的顕著に接種後の山が見ら れ，接種後それぞれ 4 日目，5日目，6日目に同様な peak が見られ $\mathrm{I} / \mathrm{H}$ 呼吸比 $1: 3$ を示し，それ以外では大 体同比 1.1 1.2 定した。すなわらタバコでは TMV 接 種により接種葉に扣いては呼吸量は接種後 3 日目頃まで は 10\%，後 4 6 日目頃に1度約 30\% に上界し，それか ら 10 日目までは 10〜20\% 増加の様相を呈した。

同時に行なったウイルス定量值とは目下比較検討中で あるが，ウィルス濃度增加曲線と呼吸比曲線と浪平行し ないようである。

11. タバコモザイクウイルスの接種葉に挌ける 初期增殖

\section{日高 酻}

（協力者：久保 進）

タバコモザイクウイルス（TMV) の接種葉に扣ける增 殖をメチル化アルブミン (MAK) カラムクロマトグラフ ィによって核酸代謝の面から検討した。 
1。ピロりん酸拼用したフェノール法によって TMV 感染組織から抽出した核酸は MAK カラム在通し ても感染性を保持していた。

2. 非感染組織加らの核酸のクロマトでは可溶性 (s) RNA, 、DNA およびりボソーム(r) RNA (18 S，28S) の順で溶出されるが，感染組織からの核酸の場合には 28Sの rRNA にやや遅れてウイルス RNA が溶出され， ての部分以外の点で洼非感染組織と感染組織とで吸光度 のパターンの上での差はみられなかった。

3.ウイルスRNA のピークは感染期間ぶ長くなるに 徒ぶって顕著になった。

4. 接種後 $12,24,48,96$ 時間目 $\left(25^{\circ}\right)$ のタバコ (Xanthi) の leaf disk ${ }^{32} \mathrm{P}$ を 30 分ないし 1 時間と りてませた場合のクロマトグラフの放射能のパターンで

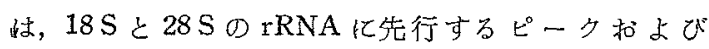

TMV-RNA に一致するピークの, 主に三つのピークが 認められたが，乙れらのピークを比較すると，TMVRNA のピークの相対的な高さは接種の 48 時間後で最高 になった。TMV-RNA 合成は接種の 12 時間あるいは 96 時間後でも認められたが，48時間後に扣いて最も盛 んであった。

5. タバコの leaf disk ${ }^{32} \mathrm{P}$ を 6 時間とりてませた 場合，その核酸のクロマトグラフの放射能のパターンは $\mathrm{OD}_{260}$ のそれに完全に一致した。との系で ${ }^{22} \mathrm{P}$ を添加す る6 時閒前からアクチノマイシン $\mathrm{D}$ 処理を行なうと rRNAへのとりとみ極度に抑えられたが，TMVRNA 合成梳とんど影響を受けなかった。ての事実は TMV-RNA の合成に DNA が関与していないという可 能性を示唆している。 


\section{0) 植物ウイルスの伝搬に関する研究}

\section{代表者 村 山 大 記 (北海道大学教授)}

\section{班員および分担研究課題}

1. アブラムシの寄主選択とキウリモザイクゥイルス の伝搬

九大農学部教授 日高 醇

2. 虫体内に打ける植物ウイルスの增殖機構

愛媛大農学部教授 吉井 啓

3. オオムギ斑葉モザイク病の種子伝染に関する研究 岡山大農業生物研助教授 并上忠 男

4. ムギ葁縮病類の土壤伝染機構化関する研究

兵庫農大助教授 宮 本 雄一

5. 機械的接種方法によるウイルス感染の機構

三重大農学部教授 平山重勝

6. 配偶子, 肧組織のウイルス感染

東大農学部教授、明日山秀文

7. 媒介昆虫体内組織に扣けるウイルスの分布ならび 亿組織培養

農林省農技研昆虫科長 深谷昌 次

8. シシャガイモ葉巻病ウイルスのアブラムシ体内に抏 ける增殖と伝染機構

農林省北海道農業試験場技官 大島 信 行

9. 虫体に対するウイルスの機械的接種と虫体内に抽 けるウイルスの増殖

北大農学部教授 村山大記

研究の目的：わが国の植物ウイルスの虫媒伝染に関す る研究は世界に魁けて多くの優れた知見を発表した。最 近世界各国に扣ける植物ウィルスの伝搬に関する研究は 著しい進展を示し，とくにその伝染機構について多くの 新らしい事実が明らか加された。るれにともなって種及 の問題が提起され，研究もとみに活発になっできた。こ の班の研究目標は植物ウィルスの伝搬の.中の主なもの,

1. 虫媒伝染 2. 種子伝染 3. 土壌伝染 4 . 汁液伝染 范 とりあげ，てれらの伝染の問題とくにその伝染機構なら びに寄生体内のウィルスの增鸨について研究するてとで ある。虫媒伝染についてはウィルス，植物ならびに昆虫 の間任見られる相互関係についての基礎的な問題につい て各方面加ら検討追求する。すなわち 伝搬の生態的な
面, ウイルス増殖の生化学的な面，保毒虫体肉のウイル スの存在様式と伝染機構, ウイルスの組織培養の問題, その他である。種々な植物ウイルスの伝搬の問題を通し て統一的な考察を得るととを最終目的としている。

本年度の研究成果と今後の計画 : 植物ウイルスの虫媒 伝染については次のような成果夲得だ。イネ萎縮病ウイ ルスの媒介昆虫ツマグロヨコバイの脂肪細胞, 腸の上皮細 胞, 唾腺招よび畉巣に招ける存在様式，とくに経畉伝染 の様式を thin sectionによって検討した。経䀦伝染に は symbiont と virion 苍含む mycetome が-つの重 要な感染の経路となっているてと学明らかにした。有翅 モモアカアブラムシとダイコンアブラムシの色彩選択とキ ウリモザイクウイルスの伝搬に扣いてアブラムシはとく に黄色に対する遛色性力強く, 主莘波長 $576 \sim 580 \mathrm{~m} \mu$,

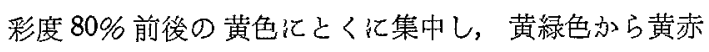
色の範囲では黄色味の強さとともにそれらの色の彩度の 強さが降下反応丟刺激した。降下反応索刺激する色彩が

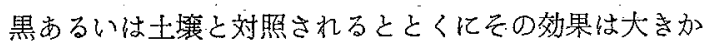
った。ジャガイモ䐑巻病ウイルスはモモアカアブラムシ により媒介されるが，Physalis floridana 接種植物と した場合, 獲得吸汁時間は 1 時間, 接種吸汁時間は 5 分 で潜伏期間は 24〜32 時間であった。な初モモアカアブ ラムシはジャガイモヒゲナガアブラムシより伝染率が高 かった。虫体に対する機械的接種により病植物, 病虫汁 液を注射すると媒介虫が保毒となり，ての方法によって ウイルスの物理的性質管知るととができだシャガイモ 葉巻病ウイルスはモモアカアブラムシに，ムギ北地モザ イクウイルスはヒメトビウンカに注射し，それぞれのウ ィルスの耐熱性・耐希秎性・耐保存性学知った。これら ウイルスの物理的性質は不明であったがかなり安定した 性質走有していると考元られる。イネ荽縮病媒介昆虫ツ マグロヨコパイより分離精製した RNA は活性を有す る。乙の活性 RNA が生体内でのタンパク合成の場に沶 いてはたす役割を追求するため，なネよりの要素により 無細胞タンパク生合成系を組立て健全活性 RNA 托よび ウイルス活性 RNA 省中心にタンパクを合成させ比較検 討を行なった。イネRNA とツマグロヨコバイ RNAで 
合成されるタンパクはをの等電点を異にし，イネ RNA により合成されるタンパクは健病間で差異が見られた。 種子伝染についてはオオムギ斑葉モザイク病では高率の 種子伝染をするてとが知られているが，実験の結果種子 の発芽前後において肧中のウイルスの不活性化あるいは ウイルスの幼植物への移行阻害があると推測された。ま たササゲ执よびアズキのモザイク病では種子伝染には配 偶子感染が一つの必要条件であるとと，植物各部位のウ イルス濃度と種子伝染の有無との間に一定の傾向か認め られないとと，種子伝染の有無と感染時期との間に密接 な関係のあるととが分り，種子伝染についてかなり具体 的な点まで判明してきた。土㙵伝染はムギ萎縮病類につ いて研究を行ない，病土にムギを播種後 1 力月以内の幼 植物体内に封入体加諰められ，またてれらウィルス粒子 はTMV 粒子似ているが，細加い点で異る所が認めら れる。てれらウイルスの伝染機構につき煤介者の存在の 有無の問題につき検討觉行っている。汁種接種について は TMV 接種源とし, Nicotiana glutinosa 飞塗抹接 種苍行ない，接種後の時間の経過を各種ウイルス不活化 物質による処理との関係について追求した。ウイルス感 染の極めて初期の段階でウイルスあるいる笴主細胞に変 化が抗とり，とれが感染営支配しているように考えられ る。

今後虫媒伝染の研究ではウイルスの虫体内増殖の問題 空組織培養法, 免疫電子影微鏡法, 虫体に対する接種 法，㟧るいは生北学的方法などによって探究し，また， ウイルス，植物，媒介昆虫の 3 者の織りなす複雑な関係 苍解析する。てれがためには病理学者，昆虫学者の強力 な結び付きが要求され，またての方向に向って進んでい る。種子伝染，土境伝染扣よび汁液伝染について最も興 味ありかつ重要な問題㤝その伝染機構である。種子伝染 については組織内のウイルスの電子影微鏡による探究， 植物とウイルスとの組合せに视ける種子伝染の実態，未 熟肧中のウイルス濃度の問題など多枓に互って研究が進

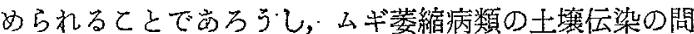
題は媒介者の有無の問題について広範囲な実験が行われ るととであろう。汁液伝染では感染を支配する要因の解 析につき表皮細胞中のエクトプラズマタ执よび毛茸の感 染の場に打ける役割について追求される。
1. アブラムシの寄主選択とキウリモザイクウ イルズの伝搬

日高 醇

（協力者：中沢邦男）

研究目的：アブラムシ類の生態; とくに有翅アブラム. シの春季移住に扣ける寄主選択行動とキウリモザイク病: の発生との関係を明らか比する。

本年度の成果：アブラムシによって非永続的に伝搬さ: れるウイルス病の畑に扣ける発生は，その大部分が烟外 部から飛来する有梖アブラムシに起因するものと考えら， れる。有翅アブラムシの作物への飛来が単に機械的なも。 のか，要るい估ら加の感覚䎲よって寄主植物を発見す るものかどうかを知るために，有翅ダイコンアブラムシ 扣よび有趐モモアカアブラムシ究対象として $2 ， 3$ の実 験を行なった。タバコの 4 品種, ブライトエロー・水戸 3 号・楽野葉・松川葉を同じ大きさに育て，各品種 30 本ずつ鉢植光とし，同時に屋外に露出した。有翅ダイコ ンアブラムシは秦野葉和よび松川葉に多く集まる傾向在 示し，キウリモザイク病の発生もとの 2 品種がやや多か った。との 2 品種は他にくらへて葉色が鮮明な黄緑色で あった。別に葉色の異なるょうに育てた銚植えのタパコ: （品種ブライトエロー）60本を用いて，アブラムシの飛: 来数苍比較した。すなわち葉の黄化が進んだブライトエ ローのうち半数觉制限光下に置いて葉色を濃緑化させ, 残りの黄緑色の葉を有するグループとともに屋外に同時 に露出したととろ，有翅ダイコンアブラムシ招よび有趐 モモアカアブラムシはともに黄緑色タバコに対し呩緑色: タバコの 1.8 倍多く飛来した。色彩に詨するアブラムシ の反応を確加めるために，緑一黄一赤にわたって 10 種 の標準色票 $(27 \mathrm{~cm}$ 四方) 学作り，粘着物塗った透明; ガラス板で覆い屋外に露出した。その結果, 有翅ダイコ ンアブラムシは 主裳波長 $576 \sim 580 \mathrm{~m} \mu$, 彩度 $80 \%$ 前後: の黄色にとくに集中し，モモアカアブラムシも同様な傾. 向を示した。黄緑色や黄赤色へは飛来数が加なり減少し たが，緑色や赤色にくらべるとはるかに多かった。有翅 アブラムシの降下反応は黄色の強さによって促進される が，その他の色についてはとくに認められなかった。黄 緑色汃黄赤色の範围では黄色昧の強さとともにそれら の色の彩度の強さが降下反応店刺激し，彩度が低下する そ黄色でさ元も飛来数はいちじるしく減少した。とくに 白色については逆にてれを忌避した。降下反応を刺激す る色彩が黒あるいは土壤と対照されるときとくにその效 果は大きく，裸地に植えられたタバコ萌がキウリモザイ ク病に䍜病し易いてとの一つの説明となるととを示し 
た。移植時期和よび施肥条件異にして栽培したタバコ の粗場加ら，彩度の高い黄緑色の葉を有する植物にはア ブラムシの飛来数が多く, ウイルス病の発生も多かっ た。

\section{2. 虫体内に扰讨々植物ウイルスの増殖機構} 吉茾啓.

研究目的：ウイルス活性 RNA ととれによるタンパク 生合成系との関連現象を解析して RNA, タンパクの構 成要素の組合わせ上での相関性を見出し，ウィルス増殖 の機作扣よび植物ウイルスの虫媒伝染の機構を解明す る。

本年度の成果：イ六萎縮病媒介昆虫ツマグロヨコバイ より，イネの場合と同様に、フェノール法で分離精製 した RNA 恬性当失なわず，保毒虫の RNA（病虫 RNA）はツマグロヨコバイを保毒化しイネ茬萎縮化す る (1964)。そてでとの活性 RNA が生体内でのタンパ ク合成の場に扣いてはたす役割を追求するため亿，まず イネよりの要素によって無細胞タンパク生合成系走組立 $\tau$. (1964 発表)，健全活性 RNA（健イネ RNA，健虫 RNA) 扣よびウィルス活性 RNA（病イネ RNA, 病虫. RNA）を中心タンパクを合成さして比較観察した。 ての結果は次の椂である。

1. イネ RNAの場合には，合成タンパクは陰イオン 性 DEAE イオン交換セルローズカラムクロマトグラ ムでは，健病両区とも分画を明汃に出来る。ただし病 RNA の方は健 RNA より分画図は単純である。

2. ッマグロヨコバイ RNA の場合には, 合成タンパ クは陽イオン性 $\mathrm{CM}$ イオン交換セルローズカラムクロ マトグラフィで分別出来るが， DEAE，セルローズでは 分画図はえられない。合成タンパクの分画には現在のと ころ健病虫間で差異はつけ難い。

以上のてとからして次のてとがわかる。

I．供陚したイネ扰よびツマグロヨコバイの健病両 RNA は，タンパク生合成には必須要素であり，かつ主 䎔性它示す。

II. イネ RNA とツマグロヨコバイ RNA で合成さ 机るタンパクはその等電点を異にする。イネRNA では 酸性側に，ッマグロヨコバイ RNA では塩基性側江等電 点をもつタンパクを合成するようである。

III. イネ RNA により合成されるタンパクは，健病 間で差異がみられれ。
3.オオムギ斑葉モ゙ザイク病の種子伝染に関す る研究

井上忠男

研究目的: 病植物種子の胚培養, 胚中ウィルス粒子の

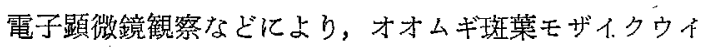
ルス (BSMV) の種子伝染機構の一端を明らかにすると とを目標とした。

\section{本年度の研究成果 :}

1. 剣吉 3 号種大麦の病種子厈中の BSMV 粒子の観 察

病種子を冷蔵庫中で 1 ～夜吸湿させ, 穎, 果種皮范 剝いで胚を露出させ, 泼の切断面を小水滴（約 $0.05 \mathrm{ml}$ ) 中に浸漬して電顕試料とした。各肧につき 2 ケの試料范 用いて BSMV 粒子の有無を観察した。20粒ずつ 5 回反 覆して 100 粒の種子を調べた。対照として同様に 100 粒 を播種し種子伝染を調べた, 電顕観察で BSMV 粒子の 確認された種子は平均 $81.0 \%$ であったが゙,対照の種子伝 染は $71.3 \%$ と約 10\%ほど低率であった。

2. 熟期を変元た病種子材料に和ける肧培養, 一粒子観， 察打よび種子伝染

ハルビン 2 条種病大麦を用い。末熟期に 2 回（でく未 熟な時期 (A) 抒よび乳熟期 (B)，切よび成熟後 (C) に 各半櫯を材料にとり, 残りの半穂は成熟後に播種して種 子伝染を調べた。 A， B , C の各材料について平均種子 伝染率は $59.3,51.2$ 七よび $67.9 \%$, 肧培養平均発病率は $76.4,53.7$ 扣よび $67.4 \%$ ，粒子検出率は $79.2 ， 82.9$ 打よ び $86.0 \%$ であった。すなわち，胚培養発病率は種子伝 染とほぼ一致し(ただし，A では一致しないが材料数 が少なかったためと思われる）たが，粒子検出率は熟期 の如何によらずほぼ常に種子伝染, 肧培養発病率よりも 大であった。

以上の成績は, 種子の熟度に関係なく胚に BSMV 粒 子を含む種子のすべてが種子伝染発病するとはが゙ら ず, また，未熟種子に扣いても胚培養発病か種子伝染発 病と変りのないてとを示している。したがって，肧中の ウイルスの不活化, あるいは, ウイルスの幼植物以の移 行阻害などがあるものとすれば，それは種子の成熟過程 途上よりは，むしろ，種子の発芽の前後ではないかと推 察さ礼る。今後はこの点に関して追求して行きたい。

4. ムギ萎縮病類の土壤伝染機構に関する研究 宮本雄 -

（協力者：宮本七ツ・竹内 正）

研究目的：ムギ萎縮病類は土壤伝染性ウィルス病の代 
表的な病害である。てれらのウイルスの土䁃伝搬機横に ついては古くから多くの研究が行なわれたが，如何なる 媒介微生物き現在までには見出されていない。私はての 点に関する実験重就結果，これらのウイルスの土壤 伝搬機構を説明するためには特定の微生物的媒介者の存 在を必らずしも必要とせず，粘土フラクションの土壤粒 子にウィルスが吸着されて安定化しているものと考える に至った。てれらの点度より広い角度と詳細な実験によ

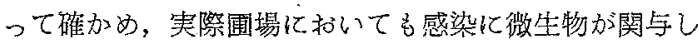
ていないかどうかを確認するととが本研究の主な目的で ある。

本年度の成果：ウイルスの性質上，今年度の最終結果 は春にならなければ得られないが，一部の実験において 次の上うな結果が得られた。

1. 従来ムギ萎縮病類は，病土に播種された場合，播

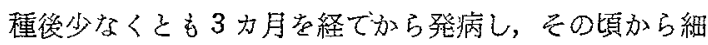
胞封入体が現われるものと考光られていたが，詳細に観 察した結果，少なくとも播種後 1 力月以内の妙植物の地 上部の細胞内に封入体が形成されるととがわかった。と の事実は今後各種の実験を行なら上有力な手がからと なるものと思われる。

2. 阪大微研の保坂氏との共同研究の結果，とれらウ イルス粒子の微細構造がかなり明らかとなった。外見は 非土壤伝搬性ウイルスの TMV 粒子と似ているが，部 分的にてわれた粒子の状態などに興味ある異なる点が認 められ，現在繼続して研究中である。

3. 室内の畭燥状態で保存したムギ萎縮病土が 9 10 年後に扔いても病原性を保持しているととがわかった。 との状驡の病土中に如何なる土壤微生物が生存している かる今後詳細代調べる予定である。

4. 才オムギ縞萎縮病に污染されている圈場で, 有機 水銀剤を中心とした土壤消毒試験を行ない，土筫菌類の 消長と本病発生との関係観察中である。ての試験の最 終結果络春を待たなければならないが，現在までに各種 試験機関で行なった類似の試験成績を調查したとてろで は，土锤菌類を対象としている有機水銀用の土壤施与は オオムギ槁萎縮病発生になんらの影響をも与えていな い。また多少の影響がみられる場合には，菌類による黄

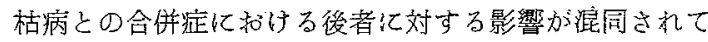
いるように思われる。

5. 関東以西の発病地を調查した結黑では，水田裏作 土壤と烟地土壤とに括沙るムギ萎縮病類の発生様相に法

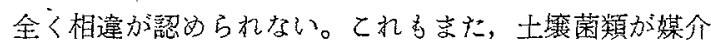
者として第 1 義的な重要性さもっているとするならば，
納得し難いととである。なぜならば，両者間の土壤微生 物相には質・量ともにかなり顕著な差汃認められている からである。

5. 機械的接種方法によるウイルス感染の機構 平山重勝

研究目的：植物ウイルス病の伝搬方法中，いわ叫る汁 液伝染，接触伝染に見られる機械的接種を支配する各種 の条件，ウィルスと寄主との関係莡追求して，機诫的接: 種方法によるウイルス感染の機構を明加にする。

本年度の成果：超遠心法によって精製したタバコモザ イクウイルス老接種源とし，寄主植物としては主として グルチノサタバコを用いた。水で稀釉したウイルスを叙: 㧲法によって接種し，その直後拉よび 30 秒， 1 分，5分 を経過してから各種のウイルス不活化物質で葉面を处理. し, 無処理の対照区との感染比率を local lesion 数に. よって算出した。

その結果は処理物質によって異るが，脺臟りボヌク レアーゼでは接種直後処理区の感染比率が最少 $(7.26 ;$ 2.63）であり，次第にてれは高くなって，5 分後の处理 では対照区の約半数 $(49.6 ; 45.6)$ となる。もっともあら かじあウィルスと䣼 $(1 \mathrm{mg} / 10 \mathrm{ml})$ を等量に混じたも。 ので接種した場合には全く local lesionを生じない。

ヨウシュヤマゴボウ葉汁液, トリプシン, 脱脂ミルク, Na-laurylsulfateでは接種直後の所理よりも接種後 30 , 秒在経て処理したものの感染比率が低く，其後時間の経: 過によって感染比率の高るる傾向が見られる。

グルタチオンで処理するとての実験範囲内では接種後 の時間の経過と共任感染比率が低下する傾向がありそう で㐫る。ただし更に時間觉延長すれれ゙前例のように再び 曲線が上向するのかも知れない。

以上 4 あるいは 2 の型が見られるが，てれらの実験は: ウイルスの機械的接種党行った場合，ウイルス感染の極 めて初期の段階に和いてウイルスあるいは寄主細胞仙変

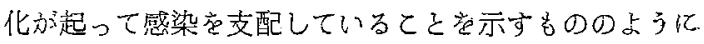
思わ机る。

な打ウイルス溶液にカーボランダム，硅藻土などを混 ヒ常温で真宝乾燥したものを用い接種試験芭行うと，て の材料に水范もとの量告で加えたもの，招よび暟燥しな い材料比し local lesion 数は著しく滅少するけれど る，な打感染性を保っている。また乾燥したウイルスに 水と付稘剂を加えたもの亿比しても感染性が劣るので, 乾燥によるウイルス精子の集合などが感染性低下の原因 かり知れないのであるが，乾燥ウイルス付傷剤と共に菜 
面に塗抹するととによって感染が起ることは興味のある てとである。

6. 配偶子; 肧組織のウイルス感染

明日山秀文

（協力者：土崎常男）

研究目的：植物ウイルス病の種子伝染は実用的にも病 理学的にも重要な問題であるが，その機構についてはな 打解明を要する問題が多く残されている。そてで主とし てアズキ扰よびササゲを材料とし，種子伝染性ウイルス と非種子伝染性ウイルンとに捛け吕行動の差異を明ら加 にし，種子伝染の基礎となる配偶子，胚組織のウイルス 感染の問題解明する。

本年度の成果：ササゲに寄生する将サゲ・モザイク・ ウイルス (2 系統), サブ・クローバー・モットル・ウィ ルス，キュウリ・モザイク・ウイルスと，アズキに笴生 するアズキ・モザイク・ウイルス, ササゲ・モザイク・ ウイルス，キュウリ・モザイク・ウイルスを用い，配偶 '子，胚組織のウイルス感染機構につき実験を行なった。

ウイルスの種子伝染, 花粉伝染, 肧のう伝染の有無と 花粉, 肧珠, 約, 子房からのウイルスの検出袁試みた。。 花粉伝染, 胚のう伝染の有無は種子伝染の有無と一致し ていた。しかし種子伝染しない抵抗性品種の黒種十六サ サゲでも，種子伝染する罹病性品種の在来蔓無金時ササ ゲの病花粉を受粉すると種子忶染蛙起った。このてとは ウイルスの種子伝染には配偶子の感染がーつの必要条件 であることを暗示している。

葯，子房からはすべてのウイルスー植物の組合わせで ウイルスが検出された。一方胚珠では大部分のウイルス 一植物の組合わせでウイルスが検出されたが，種子伝染 しないウィルス一植物の組合わせの一部で検出されない 場合が見られだ。ササゲとアズキに奇生するササゲ・モ ザイク・ウイルス学用い，紡と子房のウイルス濃度を比 較したととろ，莉では種子伝染の起るササゲが種子伝染 の起らないアズキよりもらイルス濃度が高かったが，子 房では逆であった。また燋しべ，雄しべ，花弁，葉のウ イルス濃度を各種ウイルスー植物の組合わせで調べた絬 果で出，各部位のウイルス濃度と種子伝染の有無との間 に一定の傾向は認められなふった。

植物体方ら切離さない未熟萊中の未熟肧(開花後約 10 〜15日）の一部を簬出し，種子伝染しないウイルスを汁 液接種したとてろ，低率ながら種子伀染が認められた。

開花期の植物に種子伝染するウイルスを汁液接種した ところ，接種後 20 日以後に開花したもので種子伝染が
認められだ。ウイルスはは接種後6日目に花器にすで達 しているので, 種子伝染が起るには花器原基分化完了期 までにウィルスがその近傍細胞に達しているととが必要 であること克暗示している。

\section{発 表:}

土㱦常男・明日山秀交：サザゲおよびアズキのウィル ス病の種子伝染と花器各部からのウイルス検出. 日本植 物病理学会秋季関東部会講演, 1964. 11. 7.

7. 媒介昆虫体内組織と拓けるウイルスの分布 ならびに組織培養

深谷昌次

研究目的：ウンカ ・ ヨコバイ類によって媒介される植 物ウイルスは媒介虫の体内で增殖するととが確かめられ ているが, 植物ウィルスの虫体内への侵入と增殖, 体内 での移動と経卵伝染などの機構を究明する。

\section{本年度の成果 :}

1. ツマグロヨコバイ脂肪細胞 ・消食管・睡腺・ Mycetome 扣よび射巣に扣けるイネ萎縮病ウイルス (RDV) の存在様式を明らかにした。とれら各組織の細 胞質内には viral matrix と考えられる電子密度の高い 不整形の物質があり，ての中加ら直径約 $80 \mathrm{~m} \mu$ の virion が検出された。この virion はそのまま細胞質中に遊離 する場合と,さらに一列に並らび鞘状の構造に納った状 態で遊離する場合とがある。これらの virion が増殖す る matrix 中には RDV の core の大きさに相当する 直径 $30 \sim 40 \mathrm{~m} \mu$ の小型の粒子と, 短径 $0.5 \mu$ 長径 $4 \mu$ 程 度の共棲微生物と考えられるもの和よび断面の複雑な多 重膜構造が認められた。

2. RDVがッマグロヨコバイの体内から経䀧染す る機構を明らかにした。卵采では畉巣小管の柄部の細胞 質中に viral matrix が検出され，virion もこの中から 検出された。との細胞質内には電子密度の異なる顆粒状 の共棲微生物と考えられるものが增殖し，遂にはそれが 細胞質を埋めつくして mycetome の原基を形成する。 てのとき同じ細胞質中で堌殖していた virion は共棲微 生物と考元られるものの表畨に附着した状態で存在す る。との mycetome はまもなく oöcyte へ移行するの でvirion 己同時に移行し，oöcyte が即として完成し さらに肧子発育が進むに従って RDVの増殖がるれ， 娐化前後に恃すでに mycetome 以外の組織で virion が検出され，体内で RDV が増殖している状態が観察 された。

3. Aster yellows virus (AYV) の媒介虫 Macro- 
steles fascifrons, Wound tumor virus (WTV) の媒 介虫 Agallia constricta 打よびイネ萎縮病・黄萎病の 媒介虫ツマグロヨコバイ・クロスジッマグロヨコバイな ぞの組織を培湌した。カバーグラス培養法により前記媒 介虫の細胞を培養した結果, 培養の初期に数種の細胞が 組織片から周囲人移住するの分みられた。日数の経過と ともに二次的に分化した細胞が現われ，約 1 力月培養を 継続したものでは緎維芽状細胞 2 種, 上皮細胞 5 種, 遊 離細胞 2 種が認められた。これらの細胞シートの先端で は有糸分裂が見られて増殖が旺んに行な的れるが，培養 が古くなると巨大細胞・多核細胞・倍数体細胞などが現 われる。元の組織片は培地を交換するてとといって 5 力 月以上保ち得るが, 組織片から移住した細胞を継代培養 するととはできなかった。

4. 培養した組織にウイルスを接種しその後の変化を 観察した。M. fascifrons の培養組織に AYV 保毒虫 の磨础液を加え, 24 時間後に組織の洗滌之培地の更新を 行ない $25^{\circ} \mathrm{C}$ 亿保った結果, 接種後 24 時間で細胞質内に 多数の顆粒が現われ，次第に増加して接種後 5 日目には 大部分の細胞が破買された。対照の無毒虫の磨碎液を加 えた組織にはてのような変化を生じなかったので，て の変化は AYV による影響と考元られる。また MTV 扣よびてのウイルスに近いとされる Reo virus $A$. constricta の培養組織に感染させた結果も AYV の場 合と同様であった。とくに Reo virus 接種後 $1 \sim 3$ 週 間の培地汃ら分離した液を mouse L 細胞培養法によ って活性の検定を行なった結果，ての液には Reo virus の感染性が㸾められたてとから, 培養組織でウイルスが 増殖していたものと考元られる。

8. シャガイモ葉巻病ウイルスのアブラムシ体 内に拘汀る增殖と伝染機構

大島信行

研究目的：ジャガイモ葉巻病はシャガイモ栽培上重要 なウイルス病であって，ての数年来，著しく被害が增大 しているが，そのアブラムシによる伝染機構は不明の点 が多いので，てれを明らかにして葉巻病防除法の確立に 資する。

本年度の成果：葉巻病ウイルス.のアブラムシ体内に捛 ける増殖過程を明らかにするため次の諸実験を行った。

1. アブラムシの種類に媒介能力の差異, 北海道でシ ャガイモ亿寄生するモモアカアブラムシ，ジャガイモヒ ゲナガアブラムシ及びワタノアブラムシを用いて試験を 行った。その結果, てれら 3 種のアブラムシ中，モモア
カアブラムシが媒介能力最もすぐれ，次いでシャャガイモ ヒゲナガアブラムシ，ワタノアブラムシは媒介能力を示 さなかった。実験は繰返し行ったが，夫々接種源植物や 接種植物が異るので正確なととは分らないが，全体で夫 々のアブラムシが $85 \%, 14 \%$ 及び $0 \%$ の伝搬率を 示し た。

2. モモアカアブラムシの葉巻病ウイルス獲得, 接種 及び潜伏期化必要な時間の決定,

a. ウイルス獲得所要時間 アブラムシを葉巻病纪罹 ったPhysalis floridana.上に 30 分扔よび 1 時間ずつ放 飼し，次いで健全植物上に 1 匹づつ，30 分宛移して行き 3 時間 ( 6 回移植) 継続したが, 夫々 $28 \sim 30$ 株中発病 したものはなかった。然し，10 分，1，3及び 24 時間吸 汁させてから 1 日づつ 5 日間健全植物に移して行った場 合には, 10 分吸汁では感染植物なく, 1 時間吸汁では 2 日目 (48 時間後) 加ら僅かながら伝染を起し， 3 時間, 24 時間で伝染が増加した。また，別の試験で 10，15， $20,25,30,60,120$, 及び 180 分間罹病 P. floridana 上 に，次いで 2〜5 日間健全植物上に放飼した場合にも 60 分吸汁したアブラムシが $2.9 \%$ (69 株中 2 株) の伝染を 起し，それより吸汁時間が増すと伝染率が增したが，60 分以下の吸汁では発病が見られなかった。

b. ウイルス接種所要時間 葉巻病ウイルスの強毒系 統仙罹病したP. floridana 上に飼育して打いたアブラ ムシを健全植物に. $10 ， 15 ， 25 ， 30 ， 60$ 及び 120 分放飼 したところ，10 分の加害で伝染が起った。また，別に 弱毒及び中程度の毒力のウイルス系統に罹った Datura stramonium 上で飼育したアブラムシは 5 分間の健全 $P$. floridana 加害で伝染を起した。以上の結果加らウ イルスの系統や接種源とした植物の種類で異るがも知れ ないが，保毒モモアカアブラムシは 5 分間の吸汁で伝染 を起しうるととが分った。

c. ウイルスの虫体内潜伏期間 病源 P. floridana 上で 6 時間吸汁をさせてから燥巻病に免疫性の植物（力 ブ）上に放飼して招き，一定時間後䎲 2 時間健全 $P$. floridana に移して伝染力を試験し，潜伏期間の長さを 調べた。その結果， 24 時間カブ上に 飼育したアブラム シが伝染等起した。従って潜伏期は少くとも 24〜32 時 間と思われた。

3. 保毒アブラムシの媒介能力 葉巻病に罹っだジ ガイモや前記 3 ウイルス系統に罹病した D. stramonium に夫々飼育して拁いたモモアカアブラムシを 1 匹宛 1 日 づつ新しく健全 $P$. fioridana あるいは $D$. stramonium に移して行き，10〜13 日つづけその伝染率を見た。その 
結果, 全期間に発病した植物数はアブラムシの個体で異 なりまた、ウイルスの系統によっても異らた。強毒ウ イルスの系統は弱毒ウイルス系統より伝染率が劣るよう であった。

\section{発 表:}

，大島信行・佐藤倫造：ジャガイモ葉巻病の蚜虫伝染所 要時間. 日本植物病理学会北海道部会講演, 1964. 11. 3.

大島信行・玉田哲男 : アブラムシのジャガイモ葉巻病伝 染能力. 日本植物病理学会北海道部会講演, 1964. 11. 3 .

9. 虫体に対するウイルスの機械的接種と虫体 内に和けるウイルスの増殖

村山大記

研究目的：永続的伝搬者なす植物ウイルスは一般に汁 液接種によっではつつない。したがってそれらウイル スの諸性状については詳らかではない。病植物汁液ある いは保毒昆虫体磨破汁液を処理して無毒の昆虫飞注射 し，てれを保毒せしめるととによってウイルスの諸性状 虏研究する。さらに抗血清の得られないウイルスで抗体 産生について研究し，虫体内に预けるウイルスの増殖に ついて血清学的方法によって探究したい。

\section{本年度の成果 :}

1. 北海道, 東北地方澄生するムギ北地モザイク病 について実験觉行なった。本病ウイルスはヒメトビウン． 力 (Delphacodes striatella) 扔よびジロオビウンカ D. albifasia)（本虫は 1964 年本病媒介皆虫なるとと
が判明した）によって媒介されるが，汁液伝染を行なわ ないだめにその諸性状が明らかではない。それで昆虫に 対する病植物汁液注射法に上り本ウイルスの物理的性 質，その他を知らんとして実験を行った。供試媒介虫々 してヒメトビウンカ莡用い検定植物の検索を行なった。 オオムギ・八ダカムギ・コムギ・カラスムギなどの 20 品種を用いて実験老行なったが，北斗裸が最も感受性が 高く検定植物として優れているとと老認めた。病植物 汁液を無毒ヒメトビウンカの腹部に注射して，てれを 保毒せしめるてとができた。との方法により本ウィル 又の物理的性質について研究虑行ない，耐熱性は50 $55^{\circ} \mathrm{C}$. (10 分間), 耐希採性 $10^{2} \sim 10^{3}$ 倍, 耐保存性 $4 \sim 5$ 日. $\left(5^{\circ} \mathrm{C}\right), 1$ 力月以上 $\left(-20^{\circ} \mathrm{C}\right)$ なるととが分った。、な 打本ウイルスの純化を試みつつあるが，今後ウイルスの 抗血清を得たい。

2. シシャガイモ葉巻病ウイルス罹病植物汁液あるいは 本ウイルス保毒モモアカアブラムシ拈よびジャガイモヒ ゲナガアブラムシ磨硴液の遠心上清を無毒の上記アブラ ムシに注射するてとによっててれらを保毒せしめるとと ができた。ての方法仙よててのウィルスの物理的性質 を知るととができた。この結果本ウイルスの酎熱性は 70 80 ${ }^{\circ} \mathrm{C}$. (10 分間), 耐希䣋性 $10^{3} \sim 10^{4}$ 倍, 耐保存性 $5 \sim 10$ 日 $\left(0 \sim 2^{\circ} \mathrm{C}\right.$. $), 1$ 力月以上 1 年以内 $\left(-20^{\circ} \mathrm{C}\right.$. $)$ なるととを認めた。病植物汁液を $58,000 \mathrm{G}, 1$ 時間遠心 分離した上清にも沈殿にも感染力が認められたが，後者

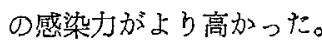

